\title{
ADUBAÇÕES CORRETIVA E DE MANUTENÇÃO E SEUS EFEITOS EM UM SOLO DE CERRADO E NA PRODUÇÃO E QUALIDADE DO ARROZ (Oryza sativa $L$.)
}

GERALDO JOSÉ APARECIDO DARIO

Orientador: Prof. Dr. FRANCISCO DE ASSIS FERRAZ DE MELLO

Dissertação apresentada à Escola Superior de Agricultura "Luiz de Queiroz", da Universidade de São Paulo, para obtenção do título de Mestre em Agronomia - Área de concentração: Solos $\theta$ Nutrição de Plantas.

PIRACICABA

Estado de São Paulo - Brasil

Agosto - 1987 
D218a

Dario, Geraldo José Aparecido

Adubação corretiva e de manutenção e seus efeitos en um solo de cerrado e na produção e qualidade do arroz (Oryza sa tiva L.). Piracicaba, 1987.

$91 \mathrm{p}$.

Diss. (Mestre) - ESALQ

Bibliografia

1. Adubação de manutenção. 2. Arroz-Adubação. 3. Arroz - Produção. 4. Arroz-Qualidade. 5. Cerrado - Solo.6. Cor retivo I. Escola Superior de Agricultura Iuiz de Queiroz, Piracicaba.

CDD 633.18

631.821 


\section{ADUBACÕES CORRETIVA E DE MANUTENCÃO E SEUS EFEITOS EM UM SOLO DE CERRADO E NA PRODUCÃO E QUALIDADE DO ARROZ (Orijza sativa $L$. )}

\section{GERALDO JOSE APARECIDO DARIO}

APROVADO EM: 03/09/87

COMISSÃO JULGADORA:

- Francisco de Assis Ferraz de Me110 ESALQ/USP

- Oswaldo Pereira Godoy ESALQ/USP

- Antonio Roque Dechen ESALQ/USP

Prof. Dr. Francisco de A. Ferraz de Mello
Orientador 
. i i .

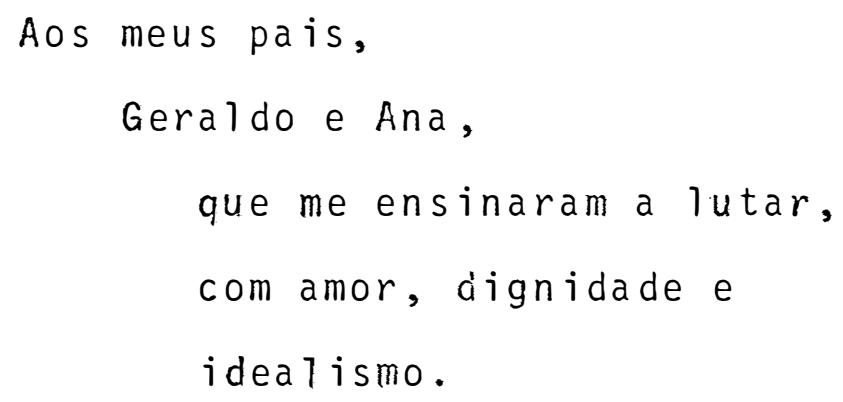


. i i i .

\section{AGRADECIMENTOS}

- Aos professores doutores Francisco de Assis Ferraz de Mello e Oswaldo Pereira Godoy, da ESALQ/USP, e ao doutor José Francisco Valente Morais, pesquisador do CNPAF/EMBRAPA, peío apoio, incentivo e competentes orientações.

- Aos professores Antonio Roque Dechen, Décio Barbin, Geraldo Victorino França, Jairo Teixeira Mendes Abrahão, Rafael Roberto Aloisi, Raul Machado Neto, Silvio Moure Cicero e Zilmar Ziller Marcos, da ESALq/USP, pelos ensinamentos e valio-. sa colaboração.

- Ao Centro Nacional de Pesquisa de Arroz e Feijão - CNPAF/EMBRAPA, em nome do doutor Almiro Blumenschein, que possibilitou a execução do presente trabaiho.

- Aos pesquisadores Francisco José Zimmermann e Noris Regina de Almeida Vieira, do CNPAF/EMBRAPA, pelos auxīios nas anālises estatisticas e testes de beneficiamento de arroz.

- Aos Engenheiros agrónomos Fá io Batista Victorino, Gisele Herbst, Mauricio Prata e Rogério Vazquez, ex-estagiärios, por diversas participações e grande amizade. 
iv.

- Ao dedicado funcionärio Adilson de Jesus Teixeira, do LAH/ /ESALQ/USP, pelo auxīlio nas anālises de laboratōrio.

- Aos anōnimos funcionārios braçais do CNPAF/EMBRAPA, que auxiliaram na instalação e condução do experimento, executando as tarefas com entusiasmo e eficiência. 


\section{INDICE}

Pàgina

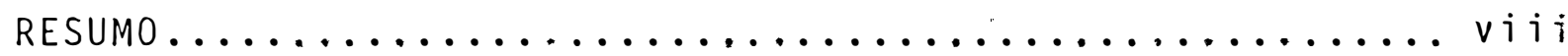

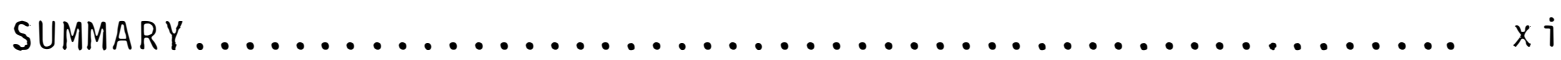

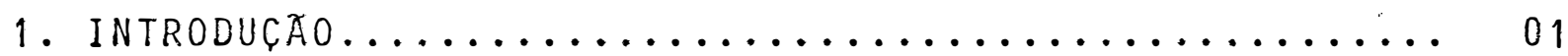

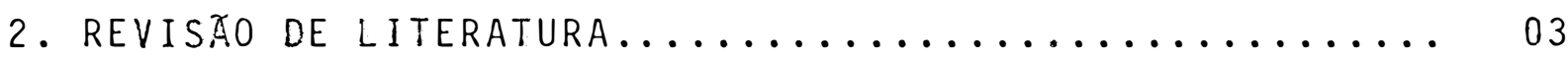

2.1. Efeitos de nutrientes minerais.............. 03

2.2. Efeitos do aluminio e da calagem.............. 11

2.3. Efeitos da matēria orgānica................ 13

2.4. Resultados de experimentacõos de adubacões corretiva e de manutenção................... 16

2.5. Resultados de experimentações com cultivares.... 25

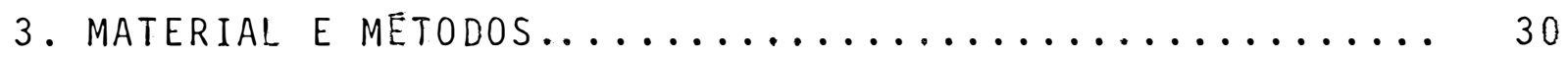

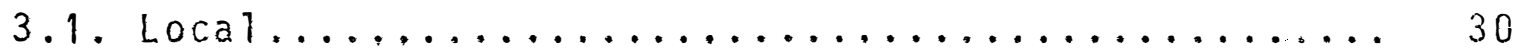

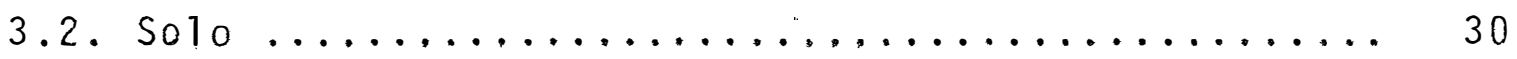

3.2.1. Anālises físicas................. 31

3.2.2. Anālises quìmicas................ 31

3.3. Delineamento estatistico.............. 32

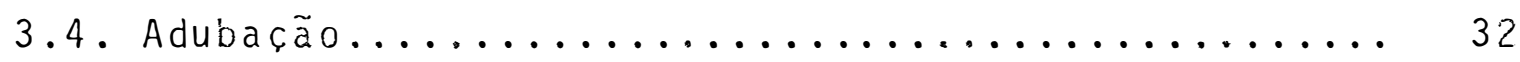

3.4.1. Adubação corretiva ............... 32

3.4.2. Adubação de manutenção............ 33

3.5. Cuttivares......................... 34

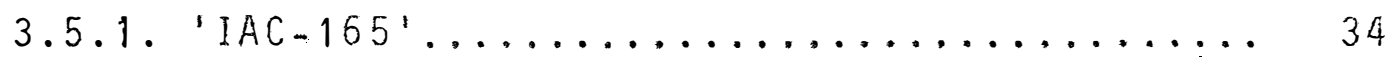




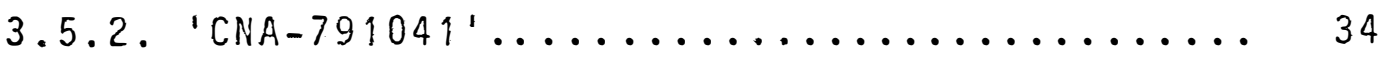

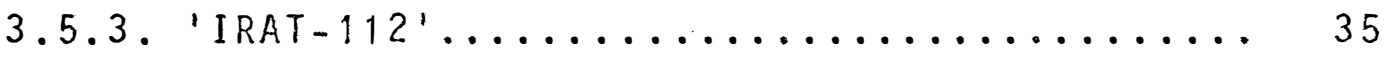

3.6. Instalação e condução do experimento.......... 35

3.6 .1 . Preparo do solo.................. 35

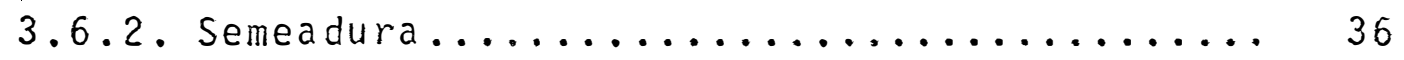

3.6.3. Tratos Culturais................ 36

3.6.3.1. Plantas daninhas........... 36

3.6 .3 .2 . Doenças................ 36

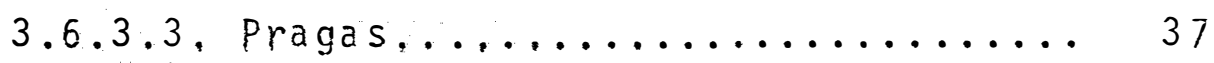

3.6 .3 .4 . Irrigação............. 37

3.7. Paràmetros analisados.................. 38

3.7.1. Desenvolvimento e produção............ 38

3.7.1.1. Número de plantas por metro..... 38

3.7.1.2. Altura das plantas.......... 38

3.7.1.3. Nümero de pan ículas por metro... 38

3.7.1.4. Producão de grãos por parcela... 38

3.7.1.5. Rendimento em grãos inteiros no berieficiamento.............. 39

3.7.2. Qualidade das sementes............ 40

3.7.2.1. Peso de 1000 sementes......... 40

3.7.2.2. Peso hectolitrico.......... 40

3.7.2.3. Poder germinativo das sementes... 41

3.7.2.4. Vigor das sementes.......... 41

3.7.3. Anàlises químicas do solo............ 41 
.vii.

Pāgina

3.8. Anālises estatisticas.................... 42

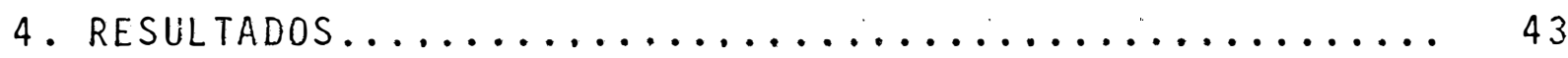

4.1. Desenvolvimento e Produção................. 43

4.1.1. Nümero de plantas por metro........... 43

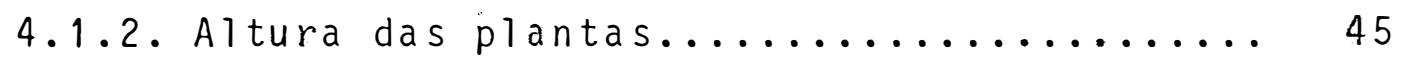

4.1.3. Nümero de paniculas por metro.......... 47

4.1.4. Producão de grãos por parcela.......... 50

4.1.5. Rendimento em grãos inteiros no beneficia-

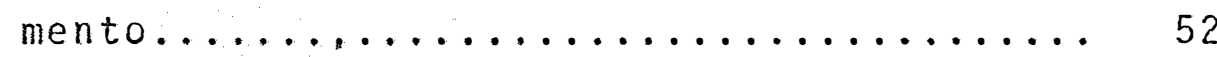

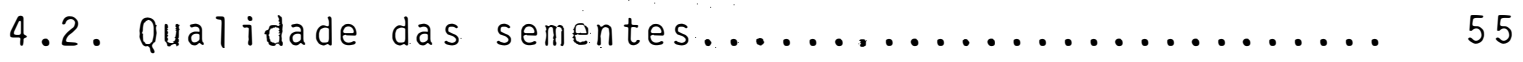

4.2.1. Peso de 1000 sementes............... 55

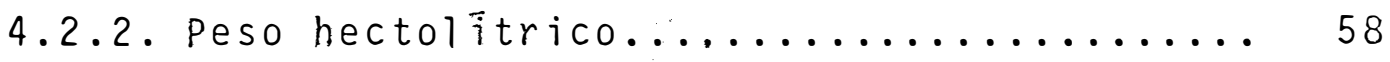

4.2.3. Poder germinativo das sementes.......... 60

4.2.4. Vigor das sementes.................. 63

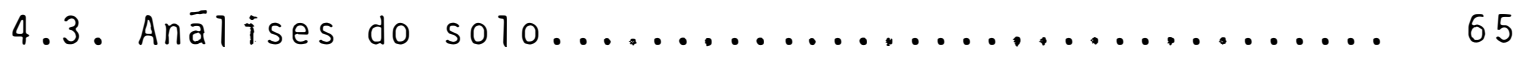

5. DISCUSSAO .......................... 68

5.1. Desenvolvimento e produção................. 68

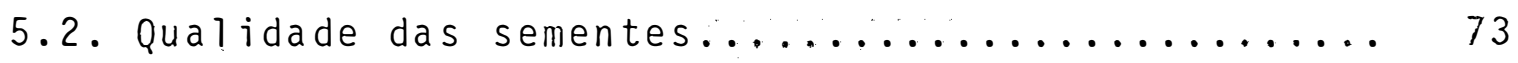

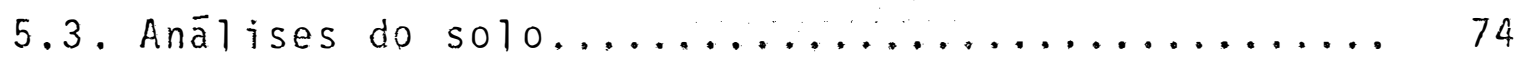

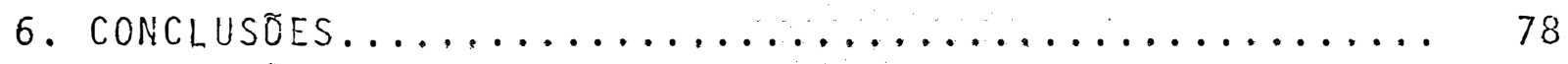

7. REFERENCIAS BIBLIOGRAFICAS ....................... 79 
.viij.

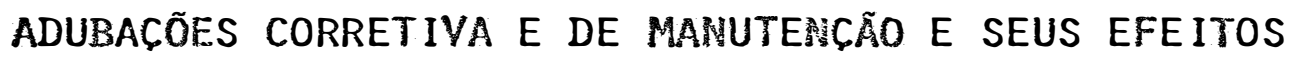 \\ EM UM SOLO DE CERRADO E NA PRODUCÃO E QUALIDADE DO ARROZ (Oryza sativa L.)
}

\author{
Autor: Geraldo Josē Aparecido Dario \\ Orientador: Francisco de Assis Ferraz de Mello
}

\section{RESUMO}

o presente trabalho visou analisar os efeitos de adubações corretiva e de manutenção nas propriedades quími cas de um solo de cerrado com dois niveis de fertilidade e no comportamento de trés cultivares de arroz.

0 experimento foi conduzido no ano agricola de 1983/84, no Centro Nacional de Pesquisa de Arroz e Feijão CNPAF/EMBRAPA, localizado no municipio de Goiānia-Go, de coor denadas $16^{\circ} 28^{\prime}$ de latitude sul, $49^{0} 17^{\prime}$ de longitude oeste e altitude de 840 metros.

0 delineamento experimental adotado nos dois locais foi um fatorial $3 \times 2$ em blocos ao acaso com quatro repe ticões. Os tratamentos constaram de três cultivares, 'IAC-

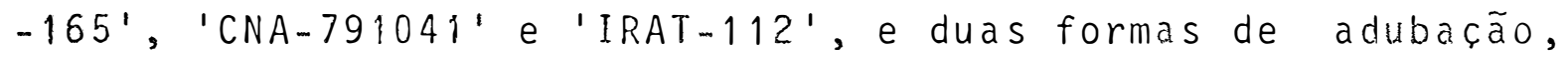
adubação de manutenção e adubação corretiva + manutenção. 
.$i x$.

matēria orgānica (palha de arroz), 3 t de calcārio dolomitico, $800 \mathrm{~kg}$ de superfosfato triplo, $20 \mathrm{~kg}$ de sulfato de zinco, $16 \mathrm{~kg}$ de sulfato de cobre, $9 \mathrm{~kg}$ de sulfato de manganēs, $9 \mathrm{~kg}$ de bōrax, $1 \mathrm{~kg}$ de molibdato de sōdio e $0,5 \mathrm{~kg}$ de sulfato de cobalto por hectare. Na adubacão de manutenção foram aplicados $40 \mathrm{~kg}$ de sulfato de amōnio, $133 \mathrm{~kg}$ de superfosfato triplo, $53 \mathrm{~kg}$ de cloreto de potāssio e $20 \mathrm{~kg}$ de sulfato de zinco por hectare, na semeadura, e $100 \mathrm{~kg}$ de sulfato de amōnio por hectare, no perfilhamento, aos trinta dias após a emergēricia das plantas.

Foram obtidos dados sobre o desenvolvimento das plantas e producão de grãos, qualidade das sementes, e realizadas añ̄ises químicas do solo antes e apōs a cultura do arroz.

os resultados, analisados estatisticamente, per mitiram as seguintes conclusões:

1) Dentre os trés cultivares utilizados, o cv. IAC-165 $\vec{e}$ o que melhor se adapta às diferentes condições de solo do cerrado, devido à sua maior produtividade e rendimento no beneficiamento. O cV. CNA-791041 e o. cV. IRAT-112 .. são indicados apenas para solos de boa fertilidade.

2) Os grãos de arroz quando produzidos em condi cões favoráveis de cultivo, e armazenados adequadamente, pode răc ser utilizados como sementes.

3) A adubação corretiva, como a utilizada no 


$$
\text { . } x
$$

experimento, melhora as propriedades quimicas do solo. Em so10 de baixa fertilidade e em condicões adversas de cultivo, essa adubação é importante no aumento da producão do arroz. Em solo de alta fertilidade e em condicões favorāveis de cul tivo, a adubacão corretiva prejudica a producão do arroz devi do ao acamamento das plantas. 
.$\times i$.

\section{CORRECTIVE AND MAINTENANCE FERTILIZATION AND THEIR EFFECTS ON A "CERRADO" SOIL AND ON THE YIELD AND QUALITY OF RICE (Oryza sativa $L_{1}$ )}

Author: Geraldo Josē Aparecido Dario Adviser: Francisco de Assis Ferraz de Mello

\section{SUPMARY}

This work had the objective of studying the behaviour or three upland rice cultivars cropped in two sites of a "cerrado" area with different levels of fertility submitted to two programs of fertilization.

The experiment was carried out in the 1983/84 cropping season at the "Centro Nacional de. Pesquisa de Arroz e Feijão" (Rice and Beans National Research Center) - CNPAF/ /EMBRAPA, Goiània-Go (16 $28^{\prime} \mathrm{S}, 49^{\circ} 17^{\prime} \mathrm{W}$ and $840 \mathrm{~m}$ of altitude).

The experimental design was a $3 \times 2$ factorial in randomized blocks with four repetitions. The treatments had three cultivars, 'IAC-165', 'CNA-791041' and 'IRAT-112', and two forms of fertilization, maintenance and corrective + maintenance fertilization.

The corrective fertilization consisted of the following rates per hectare: 20 t of organic matter (rice 
.xi i.

straw), $3 t$ of dolomitic 1 imestone, $800 \mathrm{~kg}$ of triple superphosphate, $20 \mathrm{~kg}$ of zinc sulphate, $16 \mathrm{~kg}$ of copper sulphate, $9 \mathrm{~kg}$ of manganese sulphate, $9 \mathrm{~kg}$ of borax, $1 \mathrm{~kg}$ of sodium molybdate and $0.5 \mathrm{~kg}$ of cobalt silicate. The maintenance fertilization was comprised of $40 \mathrm{~kg}$ of ammonium sulphate, $133 \mathrm{~kg}$ of triple superphosphate, $53 \mathrm{~kg}$ of potassium chloride and $20 \mathrm{~kg}$ of zinc sulphate per hectare applied at planting time, and $100 \mathrm{~kg}$ of ammonium sulphate per hectare at the beginning of tillering, thirty days after seedling emergence. The following data were collected: plant development and yield, seed quality, soil chemical analysis before planting and after the rice harvest.

The analysis of the results obtained in this work allowed the following conclusions:

1) 'IAC-165' was the best adapted cultivar to the different conditions of "cerrado" soils, considering productivity and milling. The CNA-791041 cV. and IRAT-112 cv. should be utilized only in high fertility soils.

2) Rice grains can be used as seeds when produced under good conditions of cultivation and storage.

3) The corrective fertilization used in this work improves soil chemical properties. In soils of low fertility and adverse conditions of cultivation, the corrective fertilization is an important factor for improving production. In soils of high fertility and excellent cropping conditions 
.xiii.

the corrective fertilization will render the plants susceptible to lodling. 


\section{INTRODUCÃ̃O}

A cultura do arroz é desenvolvida em todo o ter ritōrio brasileiro, apresentando ārea e produção aproximadas de 6,5 milhoẽs de hectares e 10,4 milhoẽs de toneladas.

A orizicultura no pais vem se expandindo, principalmente com o incremento de utilização de āreas de cerrado, especialmente no Brasil-Central, pois o arroz tem se mostrado como cultura mais favorável a abertura destas áreas.

No sistema de sequeiro, que representa $80 \%$ da ārea plantada, tem se obtido rendimentos muito baixos, princi palmente na região do cerrado, onde o arroz é conduzido mais como uma cultura exploratōria ou de subsistência, sem adoção de tecnologia adequada.

Além do arroz de sequeiro estar sujeito a altos riscos, devido a dependencia da regularidade da precipitação pluvial, em äreas de cerracio, com solos normalmente de baixa fertilidade, praticamente não se investe em corretivos e fertilizantes; pouco se utiliza de cultivares e sementes selecio nadas; normalmente não se aplica tratamento fitossanitário. Com isto não se pode esperar rendimentos maiores que os normalmente obtidos, em torno de $1.500 \mathrm{~kg} / \mathrm{ha}$. 
Quando se empregam cultivares nativos nao hà bom rendimento e os grãos são de qualidade inferior. São então introduzidos cultivares selecionados de regiões edafoclimāticas diferentes, procurando adaptā-los a essas variadas condições, evidentemente que esses cultivares não revelam toda sua capacidade produtiva e apresentam variacões em suas producões, principalmente relacionadas com os diferentes niveis de fertilidade dos solos em que são conduzidos.

os solos de cerrado, em condicões naturais, apresentam baixa produtividade, devido a elevada saturacão de aluminio e os baixos teores de quase totalidade dos nutrientes minerais essenciais para as plantas. Problemas ocorrem principalmente devido a deficiēncia do fósforo, cáicio, magnésio, potässio e zinco. Corrigidas estas condições adversas poderão ser obtidos altós rendimentos das culturas. o Centro Nacional de Pesquisa do Arroz e Feijão CNPAF/EMBRAPA, Goiānia-Go, através de melhoramento, vem selecionando cultivares para as āreas de cerrado, que estão sendo colocados a disposicão dos agricultores; mas tratando-se de novos cultivares, estudos devem ser desenvolvidos nas variadas condições dessas áreas, para avaliação de suas potencial i dades, aciotancio-se mocierna tecnologia de cultivo, aliada a correção dos solos e a utilização racional da adubação.

Como contribuição a esses estudos foi realizado o presente trabalho, que visa analisar os efeitos de adubacões corretiva e de manutenção nas propriedades químicas de um solo de cerrado com dois niveis de fertilidade e no compor tamento de trés cultivares de arroz. 


\section{REVISAO DE LITERATURA}

Os efeitos, importāncias e necessidades dos macro e micronutrientes, do calcārio e da matéria orgānica, assim como respostas de cultivares a diferentes niveis de aduba cão e fertilidade do solo, estão enfatizados na presente reví são.

\subsection{EFEITOS DE NUTRIENTES MINERAIS}

OLIVEIRA et alii (1964) observaram que a deficiência de nitrogénio na fase reprodutiva, ocasionou atraso na emissão das panîculas, com diminuição de tamanho e aumento de espiguetas estéreis, além de menor peso nos grãos formados.

STONE et alii (1979) estudaram as respostas de cultivares de arroz de sequeiro ao nitrogênio, correlacionando com a deficiência hîdrica, e observaram que houve resposta significativa da produção de grãos à adubação nitrogenada até $60 \mathrm{~kg}$ de N/ha quando o conteūdo de àgua não foi limitante, sen do que em condições de baixo conteūdo não houve respostas ä adubação nitrogenada. Os autores citaram que o nūmero de grãos cheios por panícula não foi afetado pelo baixo conteúdo 
de àgua no solo; entretánto houve decréscimo no nümero de panículas por $\mathrm{m}^{2}$ e no peso dos grãos, principais causas da menor produção quando a água foi limitante.

GIUDICE et alii (1979) descreveram que o nitrogênio em doses adequadas ria cultura do arroz, favorece o cres cimento das plantas, estimula o perfilhamento, melhora as caracteristicas das panículas, aumentando o nümero e o peso dos grãos. Com sua insuficiência ocorrerā reáucão no crescimento e no perfilhamento, sendo que se ocorrer deficiēncia na fase reprodutiva, ocorrerá atraso na emissão da pañicula, que será menor e apresentará grande nümero de espiguetas estéreis, a lém de menor peso dos grãos formados.

Segundo COSTA e OKUYAMA (1980), o nitrogēnio de ve ser utilizado com cautela em solos nunca cultivados, após adubação verde ou em solos de eleva fertilidade natural, pois em doses elevadas, predispõe a planta ao acamamento e ao retardamento da maturação.

A função do fósforo a cultura do arroż estā muj to relacionada com o desenvolvimento radicular, proporcionando as plantas maior resistência ao acamamento e a estresses hỉdricos; tem também importante participacão na formação e qualidade dos grãos.

Apenas 5 a $10 \%$ do fösforo aplicado como adudo E aproveitado pelas plantas de arroz que recenem a adubacão fosfatada no ano da aplicação, pois a fixação impede que 
.5 .

concentração do fósforo na solução do solo aumente muito; a liberação passarā a ocorrer quandio o poder de fixação for satisfeito.

OLIVEIRA et alii (1964) mostraram a influência altamente significativa do fósforo em arroz, no peso a parte aerea, número de panículas e peso de grãos, com maior signifi cància na produção.

Tanaka e Yoshida, citados por MALAVOLTA et alii (1974), relataram que a deficiência de fösforo em arroz deter mina atraso na maturação dos grãos, com alta porcentagem de grãos chochos.

FAGERIA (1978) verificou que aplicações de fósforo em arroz causavam aumento de matéria seca, número de perfilhos, àrea foliar, altura das plantas e produção de grãos.

VAN RAIJ et alii (1982) com base nas revisões realizadas para as diferentes regiões brasileiras sobre a adubação fosfatada, relataram que a maioria das culturas res. pondem consideravelmente a aplicação de fosfato, e em solos com deficiências acentuadas, além das adubações anuais de manutenção é necessāria a adubação corretiva, apesar dos fosfatos naturais brasileiros revelarem baixa eficiēncia agronómi$\mathrm{ca}$.

Segundo os autores, as respostas às adubações fosfatadas variam amplamente á local para local, dependendo da planta cultivada, do nivel de manejo, e principalmente da 
disponibilidade de fósforo no solo. Numa compilação de 774 ensaios realizados em diversas culturas em todo o território naciona?, observaram que as producões relativas médias dos tratamentos sem fósforo variaram de 47 a $91 \%$, indicando a necessidade da inclusão do fósforo nas a áubacões. Considera. ram que em solos muito deficientes em fósforo as respostas são mais substanciais e algumas vezes não se consegue qualquer produção sem a aplicação deste nutriente, como ocorre por exemplo na região do cerrado.

COSTA (1980) destacou que o fósforo tem sidio o nutriente mais 1 imitante para a cultura do arroz de sequei ro no Estado do Paranā, principalmente porque o arroz é considerado uma cultura rústica, sendo muito cultivado na abertura de campos nativos, na reforma de pastagens improdutivas e em cultivos consorciados, principalmente por pequenos pro. dutores, que pouco utilizam fertilizantes em suas lavouras.

Há controvérsias com relação aos resultados so bre a adubação potássica na cuitura do arroz, pois muitas ve zes a aplicação de potāssio proporcionou diminuição da produ cão, devido a salinização, ou não mostraram respostas porque o retorno nos restos de colheita é grande; apenas $5-10 \%$ do potássio é extraìdo com a colheita.

Segundo GIUDICE et alii (1979), o potássio è solicitacio em grande quantidade pela cultura do arroz para permitir producões normais; sua deficiēncia na fase de desen volvimento inicial da planta raramente será corrigida por 


\section{.7 .}

aplicações nos estágios subsequentes.

Tem-se discutido muito sobre a importância do potássio à cultura do arroz. Segundo FAGERIA (1984), o citado nutriente tem aumentacio a producão porque é requerido em vārios processos de formulação do rendimento das plantas, contribuindo para maior resistencia a doenças, formaça do $\underline{a}$ mido e transferência dos açücares, desenvolvimento da clorofila e funcionamento dos estomatos, principalmente. Sua apli cação pode ser feita a lanço, como função corretiva, visando aumentar o teor de potássio no solo; no sulco de plantio, pa ra manutenção das plantas, ou em cobertura, em āreas sujeitas a lixiviação.

A importāncia do cālcio está na manutenção da permeabilidade da membrana citoplasmātica, neutralização de àcidos töxicos e ativação de diversas enzimas. O mesmo é de fundamental importāncia à germinação dos grãos de pólen e ao crescimento do tubo polinico.

Ishibuza e Tanaka, citados por MALAVOLTA et alii (1974), concluiram que a carência de cálcio provocá diminuicão da altura das plantas, encurtamento do sistema ra dicular, redução da matéria seca e redução na produção de grãos de arroz.

O magnésio faz parte da clorofila, ativa diver sas enzimas, e também é essencial para a absorção do fósforo. GIUDICE et alii (1979) relataram que no arroz, o magnë.. sio é de grande importāncia no estímulo ao aumento de produ- 
ça. Afirmaram que a exigência do arroz em magnēsio é baixa quando comparada a outros cereais, mas mesmo assim, tem-se obtido aumentos de produção quando se lança mão de adubação suplementar de magnésio.

Não tem sido comum a aplicação de enxofre na cultura do arroz, pois as poluicões do ar e da āgua, assim como a utilização de adubos menos concentrados, jā fornecen quantidades necessārias as requeridas pelas plantas. 0 enxofre tem grande importāncia no desenvolvimento das plantas de arroz, pois faz parte de todas as proteinas vegetais e ai. guns aminoácidos, funcionando como ativador enzimático, e na fotossintese tem papel importante na sintese da clorofila.

BLAIR et alii (1978) relataram que a deficiēn.cia de enxofre em arroz afeta o crescimento, número de perfi Thos e espessura da palha; atrasa o amadurecimento e provoca chochamento dos grãos. GIUDICE et alii (1979) relataran: que o ar roz é pouco exigente em enxófre quando comparado com outras espēcies, mas quando a deficiēncia é acentuada ocorre diminuição do crescimento vegetativo e retaramento da maturaç̃̃o.

Os niveis de micronutrientes tem sido limitantes ao desenvolvimento das plantas em algumas áreas de culti vo de arroz. As condicões que podem induzir a carência de mi cronutrientes são o alto teor dematēria orgãnica, aito pH, alto teor de fósforo, solo compactado, aplicacões pesadas de calcário, solo arenoso, deficiēncia hỉarica e solos àcidos, 
principalmente. Os três ūltimos itens são comuns no cerrado. o zinco é o ūnico dos micronutrientes cuja uti lização está se tornando comum para a cultura do arroz de sequeiro, principalmente em àreas de cerrado; e os resultados de aumento no rendimento tem sido positivos com sua apli caçao. O zinco tem participação importante como ativador enzimático, sendo necessário à sintese da triptofana, que após vārias reaçōes produz o àcido indol-acético (AIA), que contribui para o aumento do volume celular.

PANDE et alii(1976) desenvolveram estudos em: vasos e em condições de campo, com a finalidade de determi nar o efeito da aplicação de Cu, Zn, B, Co e Mo, na produtividade do arroz, e concluiram que a aplicação de micronutrientes, em combinaça com $N$, $P$ e $K$, ou isoladamente, aumen tou a produtividade de grãos.

PONNAMPERUMA (1977) descreveu que a deficiēn cia de zinco em arroz é a terceira mais importante após o nitrogēnio e o fósforo.

Segundo BARBOSA FILHO e FAGERIA (1980), as plantas de arroz de sequeiro são sensiveis a deficiência de zinco, e como tem sido intensificado o plantio em solos pobres desse nutriente, pode-se considerar o zinco como sendo um dos fatores limitantes da producão de arroz. Por outro la do, CAVALCANTE et ali (1982) estudaram a influéncia ċo nitrogènio, fósforo, potássio e zinco na germinação de sementes de arroz, e concluiram que o zinco propiciou aumento da 
germinação das sementes.

Segundo KARIM e VLAMIS (1962) as exigēncias em cobre e molibdēnio são em nīveis menores do que os demais micronutrientes. Com a deficiēncia de cobre o desenvolvimento radicular é paralizado e o apical diminui sua velocidade, as paniculas do arroz são pequenas e as sementes mal formadas; quanto ao molibaénio, apesar da pequena exigência, a sua deficiēncia reduz consideravelmente a produção, apesar de não afe tar o desenvolvimento radicular e apical, mas principalmente, por acelerar o secamento das folhas. Os autores observaram tam bèm que a deficiēncia de manganès não é muito comum em solos àcidos das regiões tropicais.

MISRA et alii (1984) estudando a extração de zinco e cobre em relação ao crescimento e rendimento de doze cultivares de arroz de diferentes ciclos, observaram que a concentracão destes nutrientes nas folhas e colmos foram seme 1hantes. Reportaram também que, a absorção de ambos foi lenta durante o periodo inicial de crescimento, tornando-se vigorosa com o in $\overrightarrow{i c i o}$ do perīodo reprodutivo, até 10 dias apōs o florescimento, com concentração aumentada 30-50 dias apös o transplante. Segundo os autores, a alta concentracão de zinco e cobre na planta, durante o estāgio inicial áe crescimento, é desejāvel para manutenção do vigor. 
.11 .

\subsection{EFEItTOS DO ALUMínio E DA CALAGEM}

Numerosos trabalhos tem mostrado que existe um comportamento diferencial ao aluminio entre cultivares de uma mesma espécie, como os realizados por KERRIDGE et alii.(1971), HOWELER e CADAVID (1976), FAGERIA e ZIMMERMANN (1979) e FAGERIA (1982). For et alii (1978) discutiram que os mecanismos fisiológicos e bioquimicos pelos quais as plantas apresentaram tolerāncia ou susceptibilidade a toxidez de aluminio não são exatamente conhecidos, podendo diferir entre cultivares de uma mesma espécie.

FAHL et alii (1982) estudando o comportamento de dezesseis cultivares de arroz cultivados em solucão nutritiva, contendo ou não aluminio, observaram que a matéria seca da parte aérea e a altura das plantas foram pouco afetados pelo aluminio, e que a matéria seca das raizes mostrou tendén cia a aumentar com a presenca do aluminio, mas devido a um engrossamento e proliferação de rajzes adventicias, pois ocor reu decréscimo no comprimento do sistema radicular. os mesmos autores em trabalho semelhante, conduziram em solucão nutrit va os cultivares 'IR 665', 'IRAT 13', 'IAC 25', 'IAC 47', 'IAC 120', 'IAC 435' e 'IAC 1246' em niveis de 0,0; 5,0; 7,5 e 15,0 ppm de aluminio, e verificaram os mesmos resultados, enfatizando inclusive que os niveis de aluminio estudados diminuíram os teores de föstoro, cálcio, magnésio e zinco; aumentaram os tecres de potássio, cobre, ferro e alumí- 
nio; e nao afetaram os teores de boro e manganes, na parte aérea das plantas.

CAMARGO et alii (1983) relataram as afirmações de Cambell et alii (1978), de que os cereais diferem grandemente em suas respostas à presença de aluminio no solo, sendo a cevada mais sensivel que o trigo, e este mais sensivel que o centeio, aveia e arroz. os autores relatam também que, segundo Foy (1965) e Brown et alii (1972), entre os cultivares de uma mestia espēcie, também há diferenças quanto a tolerān cia d. aluminio no solo. Tanaka e Yoshida (1970), tambëm cita dos por CAMARGo et alii (1983), discutiram que a toxicidade de aluminio ocorre em solos ácidos, sendo considerada com um dos fatores mais limitantes da producão da cultura de arroz de sequeiro.

Com isto, os autores desenvolveram, em condicoes controladas e em solucoões nutritivas, experimento com 2 ? cultivares de arroz, para avaliar a tolerancia a diferentes niveis de aluminio, que foi medida pela capacidade das raizes primārias continuarem a crescer apōs um período de 72 horas em solução contendo uma concentração conhecida de aluminio. Os autores classificaran os cultivares em tolerantes, moderadamente tolerantes e sensiveis, mas a presenca do aluminio foi prejudicial a todos os cultivares indistintamente.

Segundo FAGERIA (1983), no pais são poucos os trabalhos de pesquisa conduzidos com a aplicação de calcārio na cultura do arroz, e destes apenas $50 \%$ tem mostrado respos- 
tas significativas; sendo que a recomendação de calagem para o arroz tem sido muito discutida e cortroverticia, apesar de considerar que a aplicacão de calcário, além dos efeitos físicos ocasiona vārias transformações quỉmicas no solo, que são significativas para o desenvolvimento das plantas, como diminuicão da concentração de ĩons $\mathrm{H}^{+}$; solubilidade do aluminio, ferro e manganēs; e disponibilidade do fósforo, potássio, cál cio, magnésio, molibdēnio e zinco; além de acentuar as atividades dos microrganismos do solo.

O mesmo autor (1984) discutiu que hä duas estra tégias para se elevar a produção nos solos ācidos: a primeira é a aplicação de adubo e calcário para aumentár o teor de nutrientes deficientes e reduzir a toxidez de aluninio; e a segunda é o uso de cultivares tolerantes à toxidez de alumi nio e mais eficientes na absorcão de fósforo, potássio, cāicio, magnésio e zinco.

\subsection{EFEITOS DA MATÉRIA ORGÂNICA}

Segundo PRIMAVESI (1968) a matéria orgānica tem importância como condicionadora de solos, pois tem a capacida de de corrigir os solos fortemente äcidos como os fortemente alcalinos, pois o prasma microbiano possue pH em torno de 6,8 e as bactérias durante a decomposicão da matéria orgānica tendem a criar no meio uma recão igual ao seu pröprio organis 
.14.

mo. Esta condição de equilíbrio é favorecida pela adicão de NPK e micronutrientes, que proporcionarão maior atividade dos microrganismos.

Ansus Jünior e Reyes (1979), citados por MACHADo et alii (1985), enfatizaram que a aplicação isolada de fer tilizantes minerais não é suficiente para a obtenção de bons rendimentos, a menos que o solo tenha um abundante suprimento de matéria orgānica.

Segundo KIEHL (1981) a importāncia da matéria orgānica pode ser evidenciada pela sua influência nas proprie dades físicas, químicas, físico-químicas e biológicas do so10. Nas propriedades químicas e fisico-quimicas ressalta-se sua importância na reação do solo, nos conteúdos de bases tro cáveis e na capacidade de troca catiônica (CTC), propriedades que contribuem no suprimento de nutrientes as plantas, destacando-se o nitrogēnio, sendo tambēri importante no fornecimento de fósforo e enxofre.

Segundo MALAVOLTA e ROCHA (1981) ns adubos orgâa nicos fornecem todos os nutrientes, incluindo os micronutrien tes, além de favorecer as propriedades físicas do solo, com evidēncia no aumento na capaciodade de armazenagem de àgua.

Baséados em trabalhos de muitos pesquisadores que tem verificado os efeitos benéficos da aplicação de resî duos orgânicos de diversas origens sobre as propriedades do solo e o rendimento de diversas culturas, MACHADO et alii (1985) conduziram experimento com a cultura do arroz, utili- 
.15 .

zando diversos materiais orgānicos, e concluiram que as aplicaçoes resultaram em significativo aumento na produção de graos, principalmente quando complementados com a adubação mi neral. Os autores citaram que a eficiencia dos residuos orgànicos salientou-se a partir do segundo ano da aplicaça (efei to residual), e que uma reaplicação a cada dois anos é recomendável para evitar redução dos seus efeitos.

KIELH (1985) relatou que, incorporando-se residuos de plantas ou animais no solo, se houver condicões de a ração e umidade suficiente e favoráveis a presença de microrganismos, haverā rāpida decomposição que decrescerá com o tem po. Na decomposição tem-se a liberação de nitrogénio, fósforo, potássio, cālcio e magnésio, que deixam a forma orgànica (imobilizada) para passarem a forma mineral (disponivel). 0 autor enfatizou também que, se o papel da matéria orgānica fosse unicamente adicionar nutrientes ao solo, especialmente o nitrogênio, teria pouca importāncia, já que a adubação mine ral age com maior precisão e eficiência; mas não, alēm das disponibilidade dos nutrientes, a matéria orgància tem grande e significativa importância nas propriedades fisicas e biológicas do solo; com isto o alitor considera a matéria orgânica como melhoradora de solos e não como fornecedora de nutrien tes, sendo sua influência importante no melhor aproveitamento de nutrientes pelas plantas e consequentemente melhor desenvolvimento destas. 
.16 .

\subsection{RESULTADOS DE EXPERIMENTACÕES DE ADUBACÕES CORRETIVA E DE MANUTENCÃO}

Procurando avaliar as respostas da aplicacão de nutrientes na cultura do arroz de sequeiro, OLIVEIRA et alii (1966) instalaram experimento em trés locais com fertilidade natural semelhantes, utilizando o cv. Dourado Precoce, e observaram respostas positivas no aumento do rendimento referente as aplicacões de nitrogênio e fósforo, enquanto que o potássio e a mistura de micronutrientes não trouxeram acrésci mos significativos na producão. Relataram também que o rendi.. mento aumentou proporcionalmente com a maior dose de fósforo (60 para $120 \mathrm{~kg}$ de $\mathrm{P}_{2} \mathrm{O}_{5} / \mathrm{ha}$ ), o que não ocorreu com o nitrogènio, obtendo-se rendimentos semelhantes nas parcelas onde aplicou-se 30 e $60 \mathrm{~kg}$ de $\mathrm{N} / \mathrm{ha}$. Os ensaios foram instalados em solos Podzolizados de Lins e Marîia, variação Lins.

MACLEOD e SUZUKI (1972) estudaram os efeitos da adubacão NPK ein solo cuja fertilidade era extremamente baixa, e verificaram que a interação Nik proporcionou maior aumento na produção do que a interação NP.

CRUZ et alii (1973) desenvolveram um experimento para observar o efeito da acubação NPK na cultura do arroz e as disponibilidades destes elementos em Terra Roxa Estruturada, utilizando o CV. IAC-1246. As quantidades dos nutrientes obedeceram trés niveis de nitrogênio, três niveis de fösforo e dois niveis de potássio, nas dosagens 0,40 e $80 \mathrm{~kg} / \mathrm{ha}$ 
de $N$ (sulfato de amōnio); 0,60 e $120 \mathrm{~kg} / \mathrm{ha}$ de $\mathrm{P}_{2} \mathrm{O}_{5}$ (superfos fato triplo); 0 e $60 \mathrm{~kg} / \mathrm{ha}$ de $\mathrm{K}_{2} 0$ (cloreto de potāssio). A anālise estatistica revelou respostas positivas às adubacões nitrogenada e fosfatada e que o tratamento $\mathrm{N}_{2} \mathrm{P}_{1} \mathrm{~K}_{0}$ apreseritou a maior produção; mas a anāi ise económica demonstrou que o me Thor tratamento correspondeu a simples aplicaça de $60 \mathrm{~kg} / \mathrm{ha}$ de $\mathrm{P}_{2} \mathrm{O}_{5}$ como superfosfato triplo.

LEITE e EIRBAUMER (1977) conduziram 24 ensaios de arroz em Podzölico Vermelho Amarelo eutrófico e Podzólico Vermelho Amarelo Concrecionārio, na região fisiogräfica dos Cocais, estado do Maranhão, Foram utilizados os cultivares 'Pratão' e 'Sagrimão' e nove tratamentos: testemunha, NP, NK, $P K, N P K, N_{2} P K, N P_{2} K, N P K_{2}$ e NPK + calcärio com doses de 0,30 e $60 \mathrm{~kg} / \mathrm{ha}$ de $\mathrm{N}$ (sulfato de amōnio); 0,60 e $120 \mathrm{~kg} / \mathrm{ha}$ de $\mathrm{P}_{2} \mathrm{O}_{5}$ (superfosfato triplo); 0,30 e $60 \mathrm{~kg} / \mathrm{ha}$ de $\mathrm{K}_{2} \mathrm{O}$ (cloreto de potássiol e 2 t/ha de calcārio. As anālises indicaram que - calcārio não influiu na producão e se resultou anti-econōmi co; que o potássio não causou aumento significativo de produção; enquanto que o nitrogènio e o fösforo apresentaram efeitos altamente significativos no aumento de producão.

MORAIS e GONTIJO (1978) estudaram as respostas da cultura do arroz de sequeiro à fertilização NPK e a calagem em quatro regióes de Minas Gerais, utilizando o cv. IAC-1246. Os tratamentos constaram de 23 das 125 combinações pos siveis de um fatorial $5^{3}$-NPK, dispostos em blocos ao acaso com 4 repeticões; foram estudados na presença e ausência de 
.18.

calagem cinco nīveis de nitrogēnio, fósforo e potássio: 0 , $30,60,90$ e $120 \mathrm{~kg} / \mathrm{ha}$, sendo que duas repeticões receberam 2,6 t/ha de calcārio calcitico com 70\% de PRNT, e duas repetí cões não foram calcariadas. Nos quatro locais os experimentos foram instalados em Latossolo Vermelho Escuro de baixa fertilidade natural. Não foram observadas respostas, a calagem com relação aos parámetros analisados: produção, perfilhamento, al tura de plantas, comprimento das paniculas e peso hectolitrico; mas com relação a adubação NPK, quando realizada, houve aumento de produção e altura de plantas, com signifiāncia para o nitrogēnio e o fósforo.

GIUDICE et alii (1979) consideraram que a nutri cão mineral adequada das plantas é responsável por 50\% do aumento da produtividade. Quanto aos macronutrientes, o problema de deficiēncia não é sério para produções de até 2 t/ha de arroz em casca, a não ser em casos especiais de solos calcários ou arenosos; entretanto, quando se pretende estabelecer alta produtividade, a aplicação de micronutrientes poderá ser necessāria. Com relação a calagem, considerando o fato de que o arroz parece desenvolver-se melhor em solos ievemente ácidos, a aplicacão de cálcário não tem demonstrado, em con dicões de campo, efeitos benéficos no aumento de producão de grãos; entretanto em alguns soros muito pesados ou sob condicões de extrema acidez, a calagem poderā acrescentar efeito benëfico para a producão de arroz, devido o estịnulo à fixacão do nitrogênio, melhoria das caracteristicas estruturais do so 
.19 .

10, aumento da disponibilidade do fósforo, maior mineraliza ção da matéria orgānica e neutralização de àcidos orgānicos tóxicos.

MACHADO et alii (1979) conduziram experimento de adubação em solo de cerrado por dois anos consecutivos. No primeiro ano aplicaram a lanço cinco níveis de fósforo na for ma de superfosfato triplo $(1,150,300,600$ e $1200 \mathrm{~kg}$ de $\mathrm{P}_{2} \mathrm{O}_{5} /$ ha), sendo cultivado sorgo nestes locais; no segundo ano nestes locais foi aplicado a mesma forma de fósforo no sulco para o plantio do arroz, em quatro niveis $(0,50,100$ e 150 $\mathrm{kg}$ de $\left.\mathrm{P}_{2} \mathrm{O}_{5} / \mathrm{ha}\right)$. No primeiro ano do experimento foram incorporados $2.500 \mathrm{~kg} / \mathrm{ha}$ de calcário dolomitico e no segundo ano aplicados $10 \mathrm{~kg}$ de $\mathrm{N} / \mathrm{ha}, 40 \mathrm{~kg}$ de $\mathrm{P}_{2} \mathrm{O}_{5} / \mathrm{ha}$ e $10 \mathrm{~kg}$ de $\mathrm{ZnSO}_{4} / \mathrm{ha}$ no sulco de semeadura, e mais $40 \mathrm{~kg}$ de $\mathrm{N} / \mathrm{ha}$ em cobertura. Foi utilizado o cv. IAC-25, e feitas as seguintes observações: que a aplicacão de fósforo a lanço, associada a aplicacão no sulco, reduziu a producão de grãos; as maiores prociucões foram ve rificadas com adubação somente no sulco de semeadura;as plantas nos niveis mais altos de adubacão apresentaram maior al tú ra, intensa infestaça o de plantas daninhas, alta percentagem de plantas acamadas e maior ataque de brusone.

FAGERIA (1980) em Latossolo Vermelho Escuro de baixa fertilidade natural realizou trés experimentos com arroz de sequeiro no cerrado e concluiu que a àgua é o fator mais limitante da produção, e quando a àgua não é o fator limitante, a deficiēncia de fósforo passa a ser. Em condicões 
normais, a aplicacão de fósforo até $150 \mathrm{~kg} / \mathrm{ha}$ de $\mathrm{P}_{2} \mathrm{O}_{5}$, aumenta a produção significativamente, mas quando a água ē limitan te hà menores respostas às adubações fosfatadas.

Kamprath (1973) citado por SMITH e SANCHEZ (1980) realizou uma revisão de pesquisas sobre solos na Améri ca Latina e observou que os solos deficientes em fósforo apre sentavam ōtimas produções de milho, soja, cana-de-açūcar e forrageiras, com aplicacões de 100 a $150 \mathrm{~kg} / \mathrm{ha}$ de $\mathrm{P}_{2}{ }^{0}{ }_{5}$, enquanto que, para o arroz de sequeiro, os niveis recomendados eram de $60 \mathrm{~kg}$ de $P_{2}$. Corcier e ininer (1975), citados pelos mesmos autores, observaram na Costa Rica, que o arroz de sequeiro não respondia a aplicação de fósforo em solos com niveis maiores que 4 ppm, mas em trabalhos realizados em Latossolo Vermelho Escuro textura argilosa sob cerrado, concluiram que o nível critico no solo está entre 2 a 5 ppm.

Estudos de oito anos realizados por CHHILLAR e SWARUP (1984) na India, mostraram que a aplicação continua de nitrogênio aumentou significativamente a producão de arroz e trigo; que aplicações de fósforo não afetaram o rendimento nos primeiros anos do experimento, quando o solo apresentava teor acima do seu nivel critico ( $5 \mathrm{ppm})$, havendo resposta quando este nível caiu, e em relação ao potássio, colheitas contiruas com arroz e trigo por oito anos não diminuiram sua disponibilidade para um nível que pudesse afetar a produção.

CARVALHo et alii (1975) estudaram os efeitos de doses crescentes de sulfato de zinco na cultura do arroz de sequeiro 
cv. IAC-1246. Os tratamentos foram $0,5,10,20,30$ e $40 \mathrm{~kg}$ de sulfato de zinco/ha com quatro repetiçoes, e o ensaio instalado em Latossolo Vermelho. Computou-se a produção de graõs e a intensidade de ocorrēncia dos sintomas de deficiēncia de zinco; a anālise estatística não revelou diferenças significa tivas entre os tratamentos, que foram superiores a testemunha, sendo a aplicação de $5 \mathrm{~kg} / \mathrm{ha}$ de sulfato de zinco no sulco de plantio suficiente para impedir a ocorréncia de deficiéncia de zinco. Os autores chegaram as mesmas conclusc̃es de SouzA e HIROCE (1970) trabalhando com o mesmo cultivar e tipo de solo em experimentos semelhantes.

Estudando o efeito de micronutrientes no rendimento e na composiçẵo quỉmica do arroz, cv. IAC-25, em solo de cerrado, GALRAO et alii (1978) concluiram que a deficiēn cia de zinco foi a ūnica que provocou decréscimo significati vo no rendimento da cultura. O experimento foi instalado em Latossolo Vermelho Escuro distrófico, textura argilosa, origi nalmente sob vegetação de cerrado, contendo oito tratamentos em blocos ao acaso com quatro repetiç̃es, constituỉdos de todos os micronutrientes (completo) e com omissão individual de boro, cobalto, cobre, ferro, manganès, molibdēnio e zinco. As parcelas receberam 5,3 t/ha de calcário dolomitico com $7.5,9 \%$ de PRNT, $30,1 \%$ de $\mathrm{CaO}$ e $19,2 \%$ de MgO; $889 \mathrm{~kg}$ de superfosfato triplo, $250 \mathrm{~kg}$ de cloreto cie potássio e $60 \mathrm{~kg}$ de enxofre elementar/ha. O nitrogènio foi aplicado em cobertura aos trin- 
.22 .

ta dias apōs a semeadura na dose de $100 \mathrm{~kg} / \mathrm{ha}$ de sulfato de amōnio, os micronutrientes aplicados na ocasião da semeadura no fundo do sulco e o fósforo, o potāssio e o enxöfre foram aplicados na ocasião do preparo do solo.

BUZETTi et alif (1981) estudaram o efeito de trēs fontes e quatro niveis de zinco sobre a cultura do arroz de sequeiro cv. IAC-25 em Latossolo Vermelho Escuro; foram feitos dez tratamentos e treze repeticões delineadas em blocos ao acaso, e a adubação básica foi de 20,80 e $60 \mathrm{~kg} /$ Tha de $\mathrm{N}, \mathrm{P}_{2} \mathrm{O}_{5}$ e $\mathrm{K}_{2} \mathrm{O}$, respectivamente. Os tratamentos utiliza dos compreenderam niveis de 5,10 e $20 \mathrm{~kg} / \mathrm{ha}$ de zinco nas for mas de cloreto de zinco, sulfato de zinco e óxido de zinco. os resultados mostraram na produção de grãos, um acrēscimo com o uso de zinco; não houve diferença significativa entre as fontes; e conclui-se que o uso de $5 \mathrm{~kg}$ de $\mathrm{Zn} / \mathrm{ha}$ para qualquer das très fontes citadas parece ser suficiente para atender as exigẽncias da cultura.

VIEIRA et alii (1987) avaliaram os efeitos do tratamento das sementes com micronutrientes (zinco, boro e co bre), sobre a produtividade e qualidade do arroz de sequeiro, cV. IAC-164. Os autores utilizaram delineamento de blocos casualizados com quatro repetiçoes e catorze tratamentos, sendo que todas as parcelas receberam adubacão básica de NPK, förmu la 5-30-15, na dose de $30 u \mathrm{~kg} / \mathrm{ha}$. Wão foi observado nenhum efeito da aplicacão isolaca de cobre e boro, e os maiores rendimentos foram obtidos com os tratamentos contendo zinco na 
dose de $150 \mathrm{~g}$ de $\mathrm{Zn} / \mathrm{ha}$.

COQUEIRO et alii (1967) não encontraram respostas significativas da aplicacão de enxofre em experimento rea lizado em trēs anos agrícolas em Sete Lagoas (MG), utilizando - cv. Dourado Precoce. O experimento foi conduzido em l.atosso 10 Vermelho Amarelo e o esquema experimental foi o de blocos ao acaso com quatro repeticões e nove tratamentos: a) testemunha; b) 1,2, 3, 4 e 5 t/ha de calcārio; c) 50,100 e 150 $\mathrm{kg} / \mathrm{ha}$ de flor de enxofre. o calcário com o enxofre foram distribuídos 50 dias antecedendo a semeadura e os resultados per mitiram concluir que o efeito do enxofre nas doses empregadas não foi significativo para o aumento de produção, sendo ... as respostas ao calcário apenas verificada a partir do segundo a no.

Em treze experimentos com arroz, conduzidos no Vale do Paraíba, estacio de São Paulo, por LEITE et alii (1979), não foi observado respostas ao calcário dolomitico.

VIEIRA et alii (1975) realizaram vários trabalhos visando estudar o efeito da calagem em arroz de sequeiro em solos de cerrado, e concluiram que a aplicacão de calcário não tem proporcionado aumentos de rendimento, enquanto que a sua aplicacão na ausência de zinco reduziu a producão, e na presença de $10 \mathrm{~kg} / \mathrm{ha}$ de sulfato de zinco a producão era igual a testemunha.

As mesmas respostas obtidas por VIEIRA et ali $i$ (1975), chegaram FAGERIA e ZIMMERMANN (1979) em experimentos 
conduzidos em condicões de campo e casa de vegetação, ou seja, que a aplicacão de calcário não tem proporcionado aumento de producão para a cultura do arroz, e sim que, a calagem na ausēncia de zinco tem reduzido a producão do arroz, enquan to que na presença de $10 \mathrm{~kg} / \mathrm{ha}$ de sulfato de zinco, a producão de areas calcariadas tem sido igual a testemunha. Mas GUAZZEL LI et alii (1973) verificaram efeito significativo de aplicacao de calcário em arroz de sequeiro, solo de textura arenosa.

PONTE et alii (1979) verificaram o efeito de doses de calcário, fósforo e zinco, e suas interacões, na pro ducão de arroz de sequeiro em um Latossolo Vermelho Escuro distrófico, textura franco arenoso, fase cerrado, localizado em Uberaba-MG. Os tratamentos com três repetições constaram de três doses de calcário $(0 ; 1,6$ e 3,3 t/ha), três níveis de fósforo $\left(60,90\right.$ e $120 \mathrm{~kg} / \mathrm{ha}$ de $\left.\mathrm{P}_{2} \mathrm{O}_{5}\right)$ e três nîveis de $z$ inco $(0,4$ e $8 \mathrm{~kg} / \mathrm{ha}$ de $\mathrm{Zn})$. Comum a todos os tratamentos aplicaram-se $150 \mathrm{~kg}$ de $\mathrm{P}_{2} \mathrm{O}_{5}$ como fosfatagem corretiva, $60 \mathrm{~kg} / \mathrm{ha}$ de $N$ divididos em duas doses iguais e aplicadas no plantio e em cobertura, e $60 \mathrm{~kg} / \mathrm{ha}$ de $\mathrm{k}_{2} 0$. O cultivar utilizado foi 0 'IAC 165' semeado 31 dias após a aplicação do calcārio com $89 \%$ de PRNT, $42 \%$ de CaO e 10\% de MgO. A análise dos dados revelou efeito significativo e positivo da calagem no acréscimo de produção; e nenhum efeito significativo de fósforo e zinco, assim como das interacões.

PONTE et alii (1971) estudaram a aplicação de 
fertilizantes e matéria orgānica na cultura do arroz, conduzi da em sistema de sequeiro em Latossolo Amarelo, em experimento levado a efeito na Escola de Agronomia da Amazonia, BelémPA. Os resultados mostraram melinores respostas para os tratamentos onde aplicou-se esterco de curral associado à adubação química e somente esterco de curral, com producões de 2.800 $\mathrm{kg} / \mathrm{ha}$ e $2.200 \mathrm{~kg} / \mathrm{ha}$ respectivamente, contra $1.200 \mathrm{~kg} / \mathrm{ha}$ obti dos na parcela testemunha sem a dubação.

Em experimentos realizados em Belēm e Capitão Poço, estado do Pará, CRUz et alii (1973) observaram que os tratamentos de adubacão mineral que continham matéria orgànica, utilizando esterco de curral, foram superiores aos sem ma tēria orgānica, na cultura do arroz de sequeiro. o experimento compreendeu quatro tratamentos: testemunha, calcārio, NPK+ calcārio e NPK, com cinco repetições, obedecendo delineamento de parcelas subdivididas, que possibilitaram testar dois niveis de matēria orgānica: 0 e 2 tha de esterco de curral. As doses empregadas de nitrogēnio, fósforo, potássio e calcārio, foram respectivamente, $10-25-25$ e $2000 \mathrm{~kg} / \mathrm{ha}$ em Belēm e $10-10-25$ e $1400 \mathrm{~kg} / \mathrm{ha}$ em Capitão Poço.

\subsection{RESULTADOS DE EXPERIMENTACÕES COM CULTIVARES}

ANDRADE e LIBONATI (1962) procuraram determi-

nar dentre os cultivares em competicão, qual o mais prociutivo 
na região de Pedreiras, Vale do Mearim-MA. Adotou-se o delineamento de blocos a acaso, com seis repeticões, com os cultivares 'Chatão', 'Iguape', 'Rizoto', 'Come-cru' e 'Saquarema'. Da anālise de variāncia de très anos em conjunto, conclui-se que nao existe nenhum cultivar que mantenha todos os anos consistentemente superior aos demais em producão.

CARMONA (1970) enfatizou que a simples utilização de cultivares que possuem elevado potencial de produção não é suficiente para aumentar o rendimento da lavoura, pois é necessārio tambēm o emprego de boas práticas culturais, entre elas a adubação. Segundo o autor, se a capacidade de produção de um cultivar for baixo, a repercussão das práticas cuI turais sobre a producão será pequena, e em muitos casos anti-econōmica; por outro lado, se cultivarmos um bom cultivar em condições adversas, a produção será inferior a que seria alcançada com um cultivar de menor capacidade de producão, porém mais rústico, pois o cultivar com alta capacidace produti va è mais exigente em fertilidade.

BANZATTO et alii (1975) relataram a iniportāncia da cultura do arroz em āreas de cerrado no estado de Goiás, e de acordo com a metodologia de adubação, que não atende as necessidades em fertilizantes e a acidez do solo, recomendam para a cultura de sequeiro o CV. IAC 1246, por apresentar maior resistência a períodos de estiagem, e em segundo lugar o 'Bico Ganga', pois embora sujeito ao acamamento e suscetibilidade a estiagem, apresenta corportamento produtivo satis 
fatörio.

FAGERIA e BARBOSA FILHO (1981) testaram cento e cinquenta cultivares de arroz de sequeiro em solo com deficiēncia de fósforo em condições de campo. Foram utilizados dois niveis de fósforo: natural do solo e $100 \mathrm{~kg} / \mathrm{ha}$ de $\mathrm{P}_{2} \mathrm{O}_{5}$, e foi constatado a possibilidade da obtencão de cultivares to lerantes ao baixo nível de fósforo.

SANTIAGO (1981) procurou verificar quais os cul tivares de arroz que se adaptam as condicões de cerrado, e testou os cultivares 'Pratão Precoce', 'IAC 25', IIAC 165', 'IAC 1131', 'IAC 5032', 'IAC 5100', 'IAC 5128', 'IAC 5544', 'IAC 47', 'Fernandes', 'Dourado Precoce', 'Batatais', 'Iguapé', 'Redondo', 'IRAT $13^{\prime}$ e 'Bico Ganga'. Foi verificado que os cultivares 'Batatais' e 'IAC 165' apresentaram melhores producões, indicando serem dois cultivares com caracteristi cas promissoras para a região do cerrado. O CV. IAC 5544 apresentou elevado perfilhamento, porēm sua produtividade não foi alta devido seu ciclo ser de 160 dias, considerado longo e afetado com maior probabilidade pelos "veranicos", que tem prejudicado na região a produção de cultivares de ciclo médio e longo. No ano seguinte trabalhou com os cultivares mais adap tāveis, dentro dos promissores previamente selecionados: 'IAC 47', 'IAC 25', 'IAC 165', 'IAC 164', 'IAC 5544', 'IAC 1131', 'Dourado' e 'Pratão Precoce', e analisou vārios parāmetros, co mo ciclo, altura da planta, número de panículas $/ \mathrm{m}^{2}$, comprimen to do cacho e producão. Observou que o cv. IAC 165 sobressaiu 
sobre os demais, iuas não houve diferenças significativas entre os cultivares testados.

Procurando-se verificar a resposta diferencial de cultivares de arroz quanto a utilização do fósforo em Latossolo Amarelo de baixa fertilidade, ocorrente nos campos cerrados de Roraima, COUTO et alii (1982) instalaram um experimento utilizarido doses de $0,50,100,150$ e $200 \mathrm{~kg} / \mathrm{ha}$ de fósforo e doses constantes de $40 \mathrm{~kg} / \mathrm{ha}$ de nitrogēnio, $30 \mathrm{~kg} /$ Tha de potássio e $20 \mathrm{~kg} / \mathrm{ha}$ de sulfato de zinco. Os cultivares utilizados foram o 'IAC 47', 'IAC 25', 'IAC 165' e 'IAC 5128'. observou-se que o fósforo foi o nutriente mais importante na produtividade do arroz, pois no tratamento que este foi omiti do, as plantas não atingiram o desenvolvimento norral e não produziram. O cV. IAC 165 apresentou maior resultado económico, pois na dosagem de $50 \mathrm{~kg}$ de $\mathrm{P}_{2} \mathrm{O}_{5} / \mathrm{ha}$ apresentou produção significativamente superior aos outros três cultivares, em to das as dosagens testadas.

FAGERIA e BARBOSA FILHO (1982) procuraram avaliar a eficiência da utilização do nitrogēnio entre 60 (sessenta) cultivares de arroz, utilizando dois niveis de nitrogê nio (25 e $85 \mathrm{~kg} / \mathrm{ha}$ ), na forma de sulfato àe amōnio; e os resultados obtidos evidenciaram diferenças na utilização do nitrogènio entre os cultivares.

Segundo FAGERIA (1984), em solos de cerrado, se o níver de cālcio e magnésio estiver em torno de $3 \mathrm{mg} / 100 \mathrm{~g}$ de solo, pode-se obter uma produção razoavelmente boa se outros 
.29 .

fatores de produção são foren limitantes; o uso de cultivares mais eficientes na utilização de calcārio e magnésio pode con tribuir ainda mais no aumento de producão.

- o autor conduziu experimentos em vasos, em casa

de vegetação, utilizando 100 (cem) cultivares de arroz, procú rando determinar a resposta à aplicação de calcário, e observou ser variável entre os cultivares, ocorrendo em média um aumento de $23 \%$ na produção de grãos com aplicação de uma dose correspondente a $4,9 \mathrm{mg}$ de $\mathrm{Ca}$ e $\mathrm{Mg} / 100 \mathrm{~g}$ de solo. 


\section{MATERIAL E METODOS}

\subsection{LOCAL}

o estudo foi real izado em ārea de cerrado

Fazenda Capivara, do Centro Nacional de Pesquisa do

Arroz e Feijão - CNPAF/EMBRAPA, localizado no municipio de Goiâniál /GO, de coordenadas $16^{\circ} 28^{\prime}$ de latitude sul, 49017' de longitu de oeste e altitude de $840 \mathrm{~m}$.

0 experimento foi instalado em dois locais com niveis de fertilidade distintos, sendo o local 01 de abertura mais recente e menor fertilidade; e o local 02, àrea à mais tempo utilizada, apresentando maior nivel de fertilidade. Nestes locais a implantaçãoe acondução da cultura do arroz sob condição de sequeiro foram idênticas.

\subsection{SOLO}

De acordo com o Levantamento de Solos do Posto Agropecuário e Fazenda Capivara - EMBRAPA/Goiás, realizado por FREITAS et alii (1975), o experimento foi instalado em La tossolo Vermelho Escuro, textura argilosa, fase cerradão sub- 
perenifōito relevo plano.

Apresenta-se a seguir a caracterização analiti-

ca do solo utilizado:

\subsubsection{ANÁLISES FISICAS}

\begin{tabular}{|c|c|c|c|c|c|c|c|c|c|c|c|}
\hline 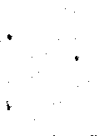 & & $\begin{array}{l}\text { Fraçöes } \\
\therefore\end{array}$ & $\begin{array}{l}\text { de amostra } \\
\%\end{array}$ & total & Con & $\begin{array}{r}\text { posicão gra } \\
\text { terra f } \\
\text { spersão com } \\
\%\end{array}$ & $\begin{array}{l}\text { nulométrica } \\
\text { Ina } \\
\text { NaOH Calgon }\end{array}$ & & \multirow{2}{*}{$\begin{array}{c}\text { Argila } \\
\text { dispersa } \\
\text { em àgua } \\
\vdots\end{array}$} & \multirow{2}{*}{$\begin{array}{c}\text { Grau de } \\
\text { floc'slasão } \\
\qquad\end{array}$} & \multirow{2}{*}{$\begin{array}{l}\text { O. Silte } \\
\text { Orgila }\end{array}$} \\
\hline Locals & $\begin{array}{l}\text { Profundidade } \\
\qquad \mathrm{cm}\end{array}$ & $\begin{array}{l}\text { Calhaus } \\
>20 \text { man }\end{array}$ & $\begin{array}{l}\text { Cascal ho } \\
20-2 \mathrm{nan}\end{array}$ & $\begin{array}{l}\text { Terra } \\
\text { fina } \\
>2 \pi m\end{array}$ & $\begin{array}{c}\text { Arcia } \\
\text { grossa } \\
2-0,20 \\
\text { mam }\end{array}$ & $\begin{array}{c}\text { Areia } \\
\text { fina } \\
0,20-0,05 \\
\text { mn }\end{array}$ & $\begin{array}{c}\text { Silte } \\
0,05-0,002 \\
\min \end{array}$ & $\begin{array}{l}\text { Argila } \\
<0,02 \\
m \pi\end{array}$ & & & \\
\hline 01 & $0-20$ & 0 & 0 & 100 & 19 & 11 & 12 & 58 & 9 & 84 & 0,21 \\
\hline 02 & $0-20$ & 0 & 0 & 100 & 21 & 18 & 10 & 51 & 19 & 63 & 0,20 \\
\hline
\end{tabular}

\subsection{2, ANÁLISES QUIMICAS}

\begin{tabular}{|c|c|c|c|c|c|c|c|c|c|c|c|c|c|c|}
\hline \multirow[b]{2}{*}{ Locais } & \multirow{2}{*}{\multicolumn{2}{|c|}{$\begin{array}{l}\text { Epocas das *profundidade } \\
\text { anälises } \mathrm{cm}\end{array}$}} & $\mathrm{pH}:$ & H.O. & $p$ & K & $\mathrm{Ca}+\mathrm{M}_{\mathrm{g}}$ & $\mathrm{Na}$ & Al & H & $\mathrm{s}$ & CTC & v & Sat. Al \\
\hline & & & $\mathrm{H}_{2} \mathrm{O}(1: 2,5)$ & 8 & ppm & & \multicolumn{6}{|c|}{ meq/100g. ifSA } & \multicolumn{2}{|r|}{ 当 } \\
\hline 01 & 1975 & $0-20$ & 5,4 & 3.6 & 1,0 & 0,09 & 0,2 & 0,02 & 0,0 & 9,1 & 0,30 & 9,40 & 3 & 0. \\
\hline 01 & 1983 & $0-20$ & 5,2 & 2,2 & 1,0 & 0,06 & 0,5 & 0,02 & 1,0 & $i, 9$ & 0,58 & 9,48 & 6 & 63 \\
\hline 02 & 1975 & $0-20$ & 5,2 & 2,9 & 1,0 & 0,07 & 0,2 & 0,02 & 0,5 & 7,1 & 0,30 & 7,90 & 4 & 56 \\
\hline 02 & 1983 & $0-20$ & 5,7 & 2,4 & 1,0 & 0,16 & 3,5 & 0,02 & 0,1 & 5,8 & 3,68 & 9,58 & 38 & 26 \\
\hline
\end{tabular}

*1975 - anälises efetuadas por ocasião do levantamento feito por fREITAS et a) i i (1975).

1983 - anālises efetuadas doismeses antes da instalação dos ensaios. 


\title{
3.3. Delineamento estat ÍSTICO
}

\author{
Em cada local foi instalado um ensaio fatorial \\ $3 \times 2$ em blocos ao acaso com quatro repeticões, cujos tratamen- \\ tos constaram de trés cultivares de arroz e dois niveis de a- \\ dubação. \\ As parcelas foram formadas de 121 inhas de ar- \\ roz espacadas de 0,5 metro, com 8,0 metros de comprimento, com \\ preendendo uma àrea de 48,0 metros quadrados.
}

\subsection{ADUBACÃO}

Nos dois locais e para cada um dos trés cultiva res foram empregados como tratamentos dois niveis de adubacão: adubação corretiva mais adubação de manutenção, e apenas aduba ção de manutenção.

\subsection{1, ADUBACÃO CORRETIVA}

"A matēria orgānica, o calcārio, o superfosfato triplo e os micronutrientes, utilizados na adubacão corretiva do solo, foram aplicados 30 dias antes da semeadura. A aplicacão foi manual a lanco e, posteriormente, feita uma gradeacão utilizando uma grade pesada de discos, para a incorporacão. 
Como fonte de matēria orgānica foi utilizado o residuo da colheita do arroz da safra anterior. Para a calagem foi utilizado calcārio dolomîtico com 89\% PRNT, 30\% de CaO e $11 \%$ de Mgo.

As doses aplicadas foram:

\begin{tabular}{lcrc} 
& & \multicolumn{2}{c}{$\mathrm{kg} / \mathrm{ha}$} \\
\cline { 2 - 4 } Produto & g/parcela & produto & nutriente \\
matéria orgānica & $96 \times 10^{3}$ & 20.000 & - \\
calcário dolomítico & $14,4 \times 10^{3}$ & 3.000 & - \\
superfosfato triplo & $3,73 \times 10^{3}$ & 800 & $350,0 \mathrm{~F}_{2} \mathrm{O}_{5}$ \\
sulfato de zinco & 105,0 & 20 & $5,0 \mathrm{Zn}$ \\
sulfato de cobre & 76,8 & 16 & $4,0 \mathrm{Cu}$ \\
sulfato de manganēs & 43,2 & 9 & $2,0 \mathrm{Mn}$ \\
börax & 43,2 & 9 & $1,2 \mathrm{~B}$ \\
mol ibdato de sōdio & 4,8 & 1 & $0,4 \mathrm{Mo}$ \\
sulfato de cobalto & 2,4 & 0,5 & $0,2 \mathrm{Co}$
\end{tabular}

\subsubsection{ADUBACÃO DE MANUTENCÃO}

A adubação de manutenção constou da aplicação no sulco, por ocasião da semeadura, de $10 \mathrm{~g}$ de fórmula 4-30. $-16+1 \mathrm{~g}$ de $\mathrm{ZnSO}_{4}$ por metro, equivalente a $8,60,32$ e $4,6 \mathrm{~kg} /$ /ha de nitrogēnio, fósforo, potássio e zinco, respectivamente.

Aos 30 dias após a emergência das plantas foi e fetuada a adubação de cobertura, aplicando-se o equivalente a 
.34 .

$20 \mathrm{~kg} \mathrm{~N} / \mathrm{ha}$, na forma de sulfato de amönio.

\subsection{CULtivares}

Foram utilizados o cV. IAC 165, atualmente com ārea significativa no cerrado, e os cultivares de introducão recente e ainda em fase experimental, o 'CNA 79-1041' e o 'IRAT-112'.

Estes cultivares apresentam as seguintes caracteristicas:

3.5.1. 'IAC-165': cultivar selecionado pelo IAC - Instituto Agronómico de Campinas e liberado em 1980, oriundo do cruzamento 'IAC $1246^{\prime} \times$ 'Dourado Precoce'; possui ciclo curto (108 a 120 dias); florescimento aos 77-83 dias; porte médio $(90 \mathrm{a} 100 \mathrm{~cm})$; moderada resistēncia a a camamento; grãos do tipo longo; casca amarelo palha; mediana susceptibilidade a brusone.

3.5.2. 'CNA 79-1041': I inhagem precoce de arroz de sequeiro (105 a 110 dias para a colheita), oriundo do cruzamento 'IAC 5544'X 'Dourado Precoce'; apresenta porte alto $\$ 120$ a $130 \mathrm{~cm})$; grãos longos; casca dourada; bom aspecto após o bene- 
ficiamento; é sensivel a brusone; tem potencial produtivo seme Thante ao CV. IAC 165.

3.5.3. 'IRAT 112': introduzido do IRAT - Instituto de Recherches Agronómicos Tropicales, sendo selecionado a partir do cruzamento 'IRAT $13^{\prime} \times$ 'Dourado Precoce'; possui ciclo curto $(105$ a 110 dias $)$; porte intermediário $(100$ a $110 \mathrm{~cm})$; boa resistência ao acamamento; grãos longos; casca dourada; é sensivel a brusone; em condições de solos mais fërteis seu rendimento tem sido 10 a $20 \%$ superior ao cV. IAC- 165 .

As sementes utilizadas foram produzidas no ano agrícola 1982/83 pelo CNPAF/EMBRAPA, e se enquadravam dentro dos padrões mỉnimos exigidos para a comercialização.

\subsection{INSTALACÃO E CONDUÇ̃̃O DO EXPERIMENTO}

\subsubsection{PREPARO DO SOLO}

o preparo do solo constou de uma aracão com arado de discos e de duas gradeacões com grade de discos; ficando o solo ra faixa preparada, de $30 \mathrm{~cm}$, descompactado e isento de torrões. 
.36 .

\subsubsection{SEMEADURA}

os sulcos foram abertos a uma profundidade de $7 \mathrm{~cm}$ e a semeadura realizada acompanhada da adubação de manutenção, utilizando uma semeadora -adubadora tipo "planet Jr." de tração manual, numa densidade de 70 sementes aptas/metro.

os experimentos foram instalados nos dias 09 e 11 de novembro de 1983 nos $10 \mathrm{ca}$ is 01 e 02, respectivamente.

\subsubsection{TRATOS CULTURAIS}

\subsubsection{Plantas daninhas}

o controle das plantas daninhas foi efetuado através de uma capina mecânica utilizando cultivador de enxadinhas aos 7 dias após a emergência das plāntulas, e mais duas capinas manuais, que foram suficientes para manter a cultura no 1 impo.

\subsubsection{Doenças}

Para o controle da brusone Pyricularia oryzae. foi feita uma aplicação de Benomyl na dose de $2,0 \mathrm{~g} / \mathrm{l}$, 
dias apōs a emergência das plantas, coincidente com o início do desenvolvimento do primórdio floral. Aos 7 e 15 dias após a primeira aplicação foi aplicado Blasticidin-S na dose de 0,2 g/l; e após mais 15 dias foi aplicado Kitazin-P na dose de 7,2 $\mathrm{g} / 1$.

Os fungicidas foram aplicados em condiçoes adequadas e com eficiencia, utilizando um pulverizador costal motorizado de 201 , a uma vasão de $1001 / \mathrm{ha}$.

\section{$3 \cdot 6 \cdot 3 \cdot 3$. Pragas}

Visando o controle de pragas de solo e da cigar rinha das pastagens, as sementes foram tratadas com Carbofuran $(525 \mathrm{~g}$ i.a./100 kg de sementes), e na ocasião da semeadura foi aplicado Quintozene $(15 \mathrm{~g}$ i.a./100 kg de sementes) misturado com as sementes.

\subsubsection{Irrigação.}

No local 01 a irrigação foi efetuada utilizando - se um caminhão tanque dotado de sistema de aspersão, e no 10cal 02 através de um sistema com aspersores fixos. 


\title{
3.7. ParÂMEtros analisados
}

\subsubsection{DESENVOLVIMENTO E PP.ODUÇÃO}

\author{
3.7.1.1. Nümero de plantas por metro. \\ As avaliacões do nümero de plantas foram feitas \\ 25 dias apōs a semeadurá, sendo efetuada contagem em 1,0 (um) \\ metro, em cada uma das cinco linhas centrais das parcelas.
}

3.7.1.2. Altura das plantas

A medida da altura foi feita quando as plantas se encontravam em fase de maturação. Foram medidas duas plantas/linha, em cada uma das cinco linhas centrais das parcelas, sendo as medicias tomadas da base da planta à inserção cia folha barieie ira.

\subsubsection{Nümero de panículas por metro \\ As avaliações dẹ nümero de paniculas foram fei-} tas na ocasião da colheita, sendo efetuada contagem das pan ĩcu las em 1,0 (um) metro em cada uma das cinco linhas centrais das parcelas.

3.7.1.4. Produção de grãos por parcela

Para avaliar a produção foram colnidos manualmente $5,0 \mathrm{~m}$ em cada um das cinco linhas centrais de cada parce 
la, correspondendo a uma ārea de $12,5 \mathrm{~m}^{2}$.

As plantas foram trilhadas e os graos secos e pesados; sendo o peso ajustado a $12 \%$ de umidade, de acordo com a fórmula empregada por TAVARES (1972):

$$
\begin{aligned}
P U=\frac{P C(1-U)}{(1-0,12)}, \text { onde: } P U & =\text { peso a umidade de } 12 \% \\
P C & =\text { peso observado } \\
U & =\text { umidade observada. }
\end{aligned}
$$

Da producão obtida foram retiradas amostras para as anālises de renaimentc cie beficiamento de grãos e quaTidáde das sementes.

3.7.1.5. Rendimento em grãos inteiros no benefi ciamento

o beneficiamento dos graos, foi realizado quatro meses apos a colheita, no Laboratōrio de Anālises de Semen tes do CNPAF/EMBRAPA, utilizando um aparelho testador de arroz marca Suzuki.

As amostras foram compostas de $100 \mathrm{~g}$ e o beneficiamento foi realizado em um tempo de 3,0 minutos, com 1,0 minuto para a operação de descascamento, e 2,0 minutos para o brunimento.

Na operação de beneficiamento houve a separação do farelo e da palha; o arroz brunido passou por um classifica dor, separando os diferentes tamanhos obtidos, sendo considera do como arroz inteiro as fracões maiores de $3 / 4$ do tamanho do grão. 


\subsubsection{GUALIDADE DAS SEMENTES}

As a nālises de qual idade das sementes foram realizadas no Laboratōrio de Sementes do Departamento de Agricultura e Horticultura da ESALQ/USP, seis meses após a colheita.

Essas sementes encontravam-se armazenadas em local ventilado em condições ambientais de umidade e temperatura.

Para controle de pragas de grãos armazenadas as se mentes foram expurgadas com fosfeto de aluminio e tratadas com inseticidas organo-fosforado Malathion $4 \% \mathrm{i}$.a. na dosagem de $1 \mathrm{~g} / \mathrm{kg}$ sementes.

\subsubsection{Peso de 1000 sementes}

Determinado em oito subamostras de 100 sementes segunaio as prescricões das Regras para Anālise de Sementes (BRA SIL, M.A., 1967). As pesagens foram efetuadas em balança com precisão de $0,1 \mathrm{~g}$.

3.7.2.2. Peso Hectolitrico

Determinado em duas subamostras em balanca hectolitrica, de capacidade de 1,0 1, segundo as prescricões das Regras para Anālises de Sementes (BRASIL, M.A.., 1967). 


\subsubsection{Poder Germinativo das sementes}

Seguiu-se as precrições indicadas pelas Regras para Anālise de Sementes (BRASIL, M.A., 1967). O substrato uti lizado foi o papel toalha da marca Xuga lavado por 24 horas em àgua corrente. Utilizou-se germinador da marca stults, regulado para temperatura alternada de 20 a $30^{\circ} \mathrm{C}$, sem a aplicacão de qualquer tratamento especial.

\subsubsection{Vigor das sementes}

o vigor das sementes foi avaliado pelo método do envelhecimento rápido, segundo procedimento descrito em ABRAHÃO e TOLEDO (1969). As sementes foram submetidas às condicões da câmara de vigor por um período de 120 horas; o substra to utilizado para a germinação após o período de permanēncia na câmara de vigor foi o mesmo citado no item anterior, mas o ger minador foi o da marca Burrows, regulado para uma temperatura de $30^{\circ} \mathrm{C}$, sem a aplicação de qualquer tratamento especial.

\subsubsection{ANÁLISES QUÍMICAS DO SOLO}

Após a colheita do arroz foram retiradas amostras do solo em todas as parcelas, nas camadas de $0-20 \mathrm{~cm}$ e 
20-40 cm de profundidade. Para cada camada e em cada uma das parcelas as amostras foram compostas de vinte tomadas simples. As anālises quïmicas para fins de fertinidacié, dos macronutrien tes e da matéria orgânica foram realizadas no Laboratōrio de Solos do CNPAF/EMBRAPA, pelo método EMBRAPA (1979) e as anälises químicas dos micronutrientes no Laboratório de Nutrição Mineral de Plantas do Departamento de Quỉmica da ESALQ/USP pe 10 método DTPA (LINDSAY e NORVELL, 1978).

\subsection{ANÁLISES ESTATÍSTICAS}

Para avaliação dos parāmetros foram feitas anālises estatísticas através do teste de $F$ e do teste de Tukey para comparação entre médias. Essas anālises foram realizadas pelo setor de Métodos Quantitativos do CNPAF/EMBRAPA, através do Pacote Estatistico SAS, utilizando computador IBM modelo 4341. 
.43 .

\section{RESULTADOS}

\subsection{DESENVOLV IMENTO E PRODUÇ̃̃O}

\subsubsection{NÚMERO DE PLANTAS POR METRO}

Na Tabela 01 sao apresentados os valores de

F para os tratamentos nos dois locais, com niveis distintos de fertilidade do solo.

De acordo com a Tabela 01 verifica-se que houve em ambos os locais, diferencas significativas entre cultivares; e no local 02 , de maior fertilidade, houve significāncia também para a interação cultivares e adubações.

TABELA 01 - Valores de $F$ e coeficiente de variação para número de plantas por metro.

\begin{tabular}{lcl}
\hline Tratamentos / Locais & 01 & 02 \\
\hline Cultivares (C) & $20,99 *$ & $91,22 *$ \\
Adubações (A) & 0,98 & 2,74 \\
Int. (CXA) & 1,54 & $7,02 * \%$ \\
Blocos & 2,86 & 2,68 \\
\hline CV $(\%)$ & 7,77 & 9,31 \\
\hline
\end{tabular}


As médias dos tratamentos e as diferencas mini mas significativas pelo teste de Tukey são apresentados nas Tabelas 02 e 03 .

As tabelas revelam que o cr. CNA 79-1041, aos 25 dias de ciclo, foi significativamente superior aos demais em relação ao maior nümero de plantas por metro; e no local 02 (Tabela 03) o cV. IAC 165 foi superior ao cV. IRAT-112. Anal isando-se a interação cultivares e adubacões no local 02, verifica-se que para o Cv. CNA 79-1041 a adubação de correção + manutenção proprocionou um aumento significativo do número de plantas em relação $\bar{a}$ simples adubação de manutenção.

TABELA 02 - Número de plantas por metro. Mëdias obtidas para os tratamentos no Local 01.

\begin{tabular}{lcccc}
\hline $\begin{array}{l}\text { cultivares } \\
\text { Adubaçães }\end{array}$ & CNA-791041 & IRAT-112 & IAC-165 & Médias \\
\hline $\begin{array}{l}\text { Correção + Manu- } \\
\text { tenção }\end{array}$ & 49,05 & 41,65 & 40,55 & 43,75 \\
Manutenção & 52,70 & 34,60 & 43,15 & 45,15 \\
\hline Médias & 50,87 & 40,62 & 41,85 & \\
\hline d.m.s. (Tukey) $5 \%$ para cultivares $=4,48$ & & \\
\hline
\end{tabular}


TABELA 03 - Nümero de plantas por metro. Médias obtidas para os tratamentos no Local 02.

\begin{tabular}{|c|c|c|c|c|}
\hline Cult tivares & CNA-791041 & |RAT-112 & IAC - 165 & Médias \\
\hline $\begin{array}{l}\text { Correção + Manu- } \\
\text { tenção }\end{array}$ & 90,70 & 44,00 & 54,40 & 63,03 \\
\hline Manutenção & 74,60 & 47,35 & 55,60 & 59,18 \\
\hline Médias & 82,65 & 45,67 & 55,00 & \\
\hline
\end{tabular}

\subsection{2, ALTURA DAS PLANTAS}

Na Tabela 04 são apresentados os valores de $F$ para os tratamentos em ambos os rocais.

De acordo com esta tabela verifica-se que houve nos dois locais, diferencas significativas entre cultivares, e no local 02, de maior fertilidade, significância entre aduba ções.

As médias dos tratamentos e as diferenças minimas significativas que comparam essas médias são apresentadas nas Tabelas 05 e 06 .

As tabelas revelam que cV. IRAT 112 apresentou altura significativamente inferiores aos outros dois cultiva 
res; e no local 01, de menor fertilidade (Tabela 05), o cv. CNA-791041 apresentou altura significativamente inferior ao CV. IAC-165. Analisando-se os tratamentos adubações no local 02, de maior fertilidade (Tabela 06), nos tratamentos adubação corretiva + manutenção a altura foi significativamente superior ao tratamento manutenção para os trés cultivares.

TABELA 04 - Valores de F e coeficiente de variação para altura das plantas.

\begin{tabular}{lcc}
\hline Tratamentos / Locais & 01 & 02 \\
\hline Cultivares (C) & $45,14 \% *$ & $135,58 \% *$ \\
Adubações (A) & 0,41 & $30,86 \% *$ \\
Int. (CXA) & 0,73 & 0,47 \\
Blocos & 0,71 & $10,99 * *$ \\
\hline CV(\%) & 5,33 & 3,62 \\
\hline
\end{tabular}

tABElA 05 - Altura das plantas $(\mathrm{cm})$. Médias obtidas para os tratamentos no Local 01.

\begin{tabular}{lcccc}
\hline Cultivares & CNA-791041 & IRAT-112 & IAC-165 & Mêdias \\
Adubaçăò & & & & \\
\hline Correção + Manutenção & 55,90 & 47,55 & 62,57 & 55,34 \\
Manutenção & 56,55 & 47,35 & 59,82 & 54,57 \\
\hline Médias & 56,22 & 47,45 & 61,20 & \\
\hline
\end{tabular}

d.m.s. (Tukey) $5 \%$ para cultivares $=3,80$ 
TABELA 06 - Altura das plantas $(\mathrm{cm})$. Médias obtidas para os tratamentos no Local 02.

\begin{tabular}{lrrrr}
\hline Cultivares & CNA-791041 & IRAT-112 & IAC-165 & Médias \\
Adubação & 95,07 & 75,60 & 97,82 & 89,50 \\
$\begin{array}{l}\text { Correção + Manu- } \\
\text { tençao }\end{array}$ & 88,65 & 66,90 & 91,75 & 82,43 \\
Manutenção & 91,86 & 71,25 & 94,78 & \\
\hline Mëdias &
\end{tabular}

d.m.s. (Tukey) $5 \%$ para cultivares $=4,04$

\subsection{3: NÚMERO DE PANÍCULAS POR METRO}

Na Tabela 07 encontram-se os valores de F para os tratamentos nos dois locais.

De acordo com essa tabela verifica-se que houve, em ambos locais, diferencas significativas entre adubaçöes; em condições de solo de menor fertilidade (local 01), - teste mostrou ainda significāncia para a interacão cultivares $x$ adubações.

As médias dos tratamentos e as diferenças miñ mas significativas para comparação dessas médias, nos dois locais, são apresentados nas Tabelas 08 e 09.

Comparando-se as médias para adubações observa-se que o tratamento correcão + adubacão proporcionou sign $\underline{i}$ ficativamente maior número de panículas por metro em ambos 
os locais. Na interação cultivares dentro de adubação, local 01, de menor fertilidade (Tabela 08) observa-se que den tro do tratamento adubação de correção + manutenção, 0 cv. CNA 79-1041 produziu menor nūmero de panículas por metro do que os outros dois cultivares; analisando-se por outro lado, os efeitos das adubações dentro de cultivar, observa-se a superioridade da adubacão de correção + manutenção sobre a adubação apenas de manutenção, que determinou aumento significativo do número de panículas por metro, dos cultivares 'IRAT$-112^{\prime}$ e 'IAC-165'.

TABELA: 07 - Valores de $F$ e coeficiente de variação para número de panículas por metro.

\begin{tabular}{llc}
\hline Tratamentos / Locais & 01 & 02 \\
\hline Cultivares (C) & 1,59 & 2,72 \\
Adubações (A) & $9,57 * *$ & $13,86 * *$ \\
Int. (CXA) & $4,71 *$ & 0,14 \\
Blocos & 2,48 & 1,87 \\
CV(\%) & 10,48 & 11,70 \\
\hline
\end{tabular}


TABELA 08 - Número de panículas por metro. Médias obtidas para os tratamentos no Local 01.

Adubação

CNA-791041 IRAT-112 IAC-165 Médias

\begin{tabular}{|c|c|c|c|c|}
\hline $\begin{array}{l}\text { Correção + Manu- } \\
\text { tenção }\end{array}$ & 47,50 & 58,25 & 59,25 & 55,00 \\
\hline Manutenção & 50,25 & 46,50 & 47,75 & 48,16 \\
\hline Médias & 48,87 & 52,37 & 53,50 & \\
\hline
\end{tabular}

d.m.s. (Tukey) 5\% para cultivares $=7,02$

d.m.s. (Tukey) $5 \%$ para cultivares dentro de adubação $=9,92$

d.m.s. (Tukey) $5 \%$ para adubaçẽes dentro de cultivar $=8,14$

TABELA 09 - Nümero de panículas por metro. Médias obtidas para os tratamentos no Local Oź.

\begin{tabular}{lcccc}
\hline Cultivares & CNA-791041 & IRAT-112 & IAC-165 & Médias \\
\hline $\begin{array}{l}\text { Correção + Manu- } \\
\text { tenção }\end{array}$ & 101,00 & 93,00 & 87,50 & 93,83 \\
Manutenção & 82,75 & 80,00 & 72,75 & 78,50 \\
Médias & 91,87 & 86,50 & 80,12 & \\
\hline
\end{tabular}

d.m.s. (Tukey) $5 \%$ para cultivares $=13,10$ 


\subsection{4, PRODUÇ̃̃O DE GRÃOS POR PARCELA}

Na Tabela 10 são expressos os valores de $\mathrm{F}$ para os tratamentos nos dois locais.

Verifica-se nessa tabela que houve no local 01, de menor fertilidade, significāncia para cultivares, adubacões e para a interacão cultivares $x$ adubacões; no local 02, de maior fertilidade, não ocorreu significāncia entre os tratamentos.

TABELA 10 - Valores de $F$ e coeficiente de variação para produção de graõs por parcela.

\begin{tabular}{lcl}
\hline Tratamentos / Locais & 01 & 02 \\
\hline Cultivares (C) & $39,34 \% *$ & 0,02 \\
Adubação (A) & $11,32 * *$ & 0,45 \\
Int. (CXA) & $8,41 * *$ & 3,47 \\
Blocos & $6,32 \% *$ & $8,26 * *$ \\
\hline CV(\%) & 15,15 & 9,91 \\
\hline
\end{tabular}

As médias dos tratamentos e as diferencas min $\underline{i}$ mas significativas pelo teste de Tukey para ambos os locais, são apresentados nas Tabelas 11 e 12 . 
No local 01, de menor fertilidade (Tabela 11), a anālise comparativa das médias entre cultivares revela que as produções dos cultivares 'CNA-791041' e 'IRAT-112', foram significativamente inferiores a o do cV. IAC-165, tomado como testemunha.

TAEELA 11 - Produção de grãos por parcela (gramas). Médias obtidas para os tratamentos no Local 01.

\begin{tabular}{|c|c|c|c|c|}
\hline 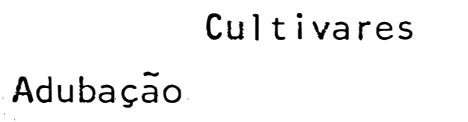 & CNA-791041 & IRAT-112 & $\mid A C-165$ & Médias \\
\hline Correção + Manutenção & 743,50 & 863,00 & 1549,25 & 1051,91 \\
\hline Manutenção & 867,50 & 602,25 & 1091,00 & 853,58 \\
\hline Médias & 805,50 & 732,60 & 1320,10 & \\
\hline
\end{tabular}

d.m.s. (Tukey) $5 \%$ para cultivares $=187,55$

d.m.s. (Tukey) 5\% para cultivares dentro de adubação $=264,99$

d.m.s. (Tukey) $5 \%$ para adubações dentro de cultivar $=217,33$

Comparando-se os tratamentos adubações, ressalta-se atravēs das médias, a importāncia da adubação corretiva em solo de baixa fertilidade, obtendo-se produção significati vamente superior do tratamento correção + manutenção sobre o tratamento manutenção. Porēm os resultados das anālises mostraram também significāncia para a interação cultivares e adu 
bações; pela anālise dessa interação verifica-se que o cv. IAC-165 é o mais produtivo, quer sob a adubação de correção mais manutenção, quer sob apenas a adubação de manutenção, e esse cultivar, juntamente com o 'IRAT-112', respondeu melhor a correção do solo, com aumento da producão, conforme se veri fica pela anālise comparativa de suas médias dentro dos tratamentos adubações.

TABELA 12 - Produção de grãos por parcela (gramas). Médias obtidas para os tratamentos no Local 02.

\begin{tabular}{lrrrr}
\hline Cultivares & CNA-791041 & IRAT-112 & IAC-165 & Médias \\
Adubações & & 5482,0 & 5021,0 & 5132,4 \\
\hline Correção + Manutenção & 4894,2 & 4601,2 & 5108,0 & 4995,5 \\
Manutenção & 5277,2 & 5041,6 & 5064,5 & \\
\hline Médias & 5085,8 & & \\
\hline d.m.s. (Tukey) 5\% para cultivares $=652,05$ & &
\end{tabular}

\subsubsection{RENDIMENTO EM GRÃOS INTEIROS NO BENEF ICIAMENTO}

Na Tabela 13 são encontrados os valores de $F$ para os tratamentos nos distintos locais.

De acordo com a referida tabela verifica-se que houve em ambos os locais diferencas significativas para 
.53 .

cultivares; e no local 02, de maior fertilidade, significāncia para a interação cuitivares $x$ adubações.

As médias dos tratamentos e as diferencas minimas significativas pelo teste de Tukey para os locais 01 e 02 são apresentados nas Tabelas 14 e 15 , respectivamente.

TABELA 13 - Valores de $F$ e coeficiente de variação para rendimento emgrãos inteiros no beneficiamento.

\begin{tabular}{lll}
\hline Tratamentos / Locais & \multicolumn{1}{c}{01} & 02 \\
\hline Cultivares (C) & $18,72 * *$ & $8,20 * *$ \\
Adubaçöes (A) & 0,95 & 0,00 \\
Int. (CXA) & 3,01 & $7,07 * *$ \\
Blocos & 1,89 & 0,61 \\
\hline CV(\%) & 18,45 & 4,53 \\
\hline
\end{tabular}

No $l o c a l$ 01, de menor fertilidade, os cultivares tiveram um rendimento muito baixo, conforme se constata atravēs da Tabela 14. Dos trés cultivares, o cV. IRAT-112 foi o de maior quebra de grãos, apresentando um rendimento médio significativamente inferior aos cultivares 'CNA 79-1041'. e

'IAC-165'. Em condições de maior fertil idade (10cal 02), o CV. IRAT-112 voltou a apresentar menor rendimento em graós 
inteiros (Tabela 15), com média significativamente inferior a dos outros dois cultivares.

TABELA 14 - Rendimento em grãos inteiros no beneficiamento (\%). Mëdias ob tidas para os tratamentos no Local 01.

\begin{tabular}{lcccc}
\hline Cultivares & CNA-791041 & IRAT-112 & IAC-165 & Médias \\
Adubações & & & & \\
\hline Correção + Manutenção & 37,21 & 26,27 & 38,28 & 33,92 \\
Manutenção & 43,27 & 18,54 & 32,75 & 31,52 \\
\hline Mëdias & 40,24 & 22,40 & 35,52 & \\
\hline d.m.s. (Tukey) 5\% para cultivares $=7,84$ & & \\
\hline
\end{tabular}

Nesse locál registra, quando se analisa o comportamento dos cultivares dentro dos tratamentos adubacões, que para o cV. CNA 791041, maior rendimento em grãos inteiros foi obtido com a adubação de manutenção. 
TABELA 15 - Rendimento em grãos inteiros no beneficiamento (\%). Mëdias ob tidas para os tratamentos no Local 02.

\begin{tabular}{|c|c|c|c|c|}
\hline \multirow[b]{2}{*}{ Correção + Manutenção } & $V A-791041$ & \multirow{2}{*}{$\frac{\mid \text { IRAT }-112}{53,20}$} & \multirow{2}{*}{$\frac{1 A C-165}{62,19}$} & \multirow{2}{*}{$\begin{array}{r}\text { Médias } \\
59,60\end{array}$} \\
\hline & 58,43 & & & \\
\hline Manutenção & 64,21 & 54,65 & 59,80 & 59,55 \\
\hline Médias & 61,32 & 56,42 & 60,99 & \\
\hline
\end{tabular}

d.m.s. (Tukey) $5 \%$ para cultivares $=3,51$

d.m.s. (Tukey) $5 \%$ para cultivares dentro de adubação $=4,96$

d.m.s. (Tukey) $5 \%$ para adubações dentro de cultivar $=4,07$

\subsection{QUALIDADE DAS SEMENTES}

\subsubsection{PESO DE 1OCG SEMENTES}

Na Tabela 16 são apresentados os valores de $F$ para os tratamentos em ambos os locais.

De acordo com esta tabela, verifica-se que hou ve nos locais, com niveis distintos de fertilidade, diferen cas significativas para cultivares; no local 01 , de menor fertilidade, houve significância para a interação cultivares $x$ adubações; e no local 02 , de maior fertilidade, significàn- 
cia para adubações.

TABELA 16 - Valores de $F$ e coeficiente de variação para peso de 1000 sementes.

\begin{tabular}{lll}
\hline Tratamentos ; Locais & 01 & 02 \\
\hline Cultivares (C) & $3,85 *$ & $39,40 * *$ \\
Adubações (A) & 0,83 & $25,54 * \%$ \\
Int. (CXA) & $4,43 *$ & 1,45 \\
Blocos & 1,95 & 0,59 \\
\hline CV(\%) & 3,64 & 2,80 \\
\hline
\end{tabular}

As médias dos tratamentos e as diferencas minn mas pelo teste de Tukey para os Tocais 01 e 02 são apresentados nas tabelas 17 e 18 , respectivamente.

Comparando-se os cultivares no local 01, em condições de solo de menor fertilidade (Tabela 17), o cv. IRAT-112, de maior média para peso de 1000 sementes, foi significativamente superior apenas ao cr. CNA 791041 , sendo que no local 02, de maior fertilidade (Tabela 18), ele se destacou significativamente tanto do 'CNA 79-1041' quanto do 'IAC 165 '. 
TABELA 17 - Peso de 1000 sementes (gramas). Mëdias obtidas para os tratamentos no Local 01.

\begin{tabular}{|c|c|c|c|c|}
\hline Adubaçōes & CNA-791041 & IRAT -112 & $1 A C-165$ & Mëdias \\
\hline Correção + Manutençã & 24,90 & 25,67 & 26,30 & 25,62 \\
\hline Manutenção & 25,47 & 27,30 & 25,15 & 25,97 \\
\hline Médias & 25,18 & 26,48 & 25,72 & \\
\hline \multicolumn{5}{|c|}{ d.m.s. (Tukey) $5 \%$ para cultivares $=1,22$} \\
\hline \multicolumn{5}{|c|}{ d.m.s. (Tukey) $5 \%$ para cultivares dentro de adubação $=1,73$} \\
\hline \multicolumn{5}{|c|}{ d.m.s. (Tukey) $5 \%$ para adubações dentro de cultivar $=1,41$} \\
\hline
\end{tabular}

TABELA 18 - Peso de 1000 sementes (gramas). Médias obtidas para os tratamentos no Local 02 .

\begin{tabular}{l|cccc}
\hline Cultivares & CNA-791041 & IRAT-112 & IAC-165 & Médias \\
Adubações & & 36,22 & 32,00 & 33,40 \\
\hline Correção + Manutenção & 31,97 & 37,47 & 34,87 & 35,39 \\
\hline Manutenção & 33,82 & 36,85 & 33,43 & \\
\hline Médias & 32,90 & & \\
\hline d.m.s. (Tukey) $5 \%$ para cultivares $=1,25$ &
\end{tabular}


.58 .

Anal isando-se a interação cultivares $x$ adubacões na Tabela 17, verifica-se que em solo de baixa fertilidade, o cv. IRAT-112, sob adubação apenas de manutenção, apresentou média estatisticamente superior a da adubaça correcão + manutenção, como também maior peso de 1000 sementes que os outros dois cultivares.

No local 02, ae maior fertilidade (Tabela 18), o peso de 1000 sementes foi significativamente superior onae se fez apenas a adubação de manutenção.

\subsubsection{PESO HECTOLÍTRICO}

Na Tabela 19 são apresentados os valores de F para os tratamentos nos dois locais.

Esta Tabela 19 mostra que houve em ambos os locais diferencas significativas para cultivares; e no local 02 , de maior fertilidade, também significância para adubações.

As médias dos tratamentos e as diferenças min $\underline{i}$ mas significativas pelo teste de Tukey para ambos os locais, se encontram nas Tabelas 20 e 21.

Para comparações entre as médias dos cultivares para peso hectolitrico, atravēs do teste de Tukey, tem-se que, no rocal 01, de menor fertilidade (Tabela 20), o cy. CNA-791041 apresentou maior valor médio significativamente diferen- 
te dos dois outros cultivares, e no 10cal 02, de maior ferti1 idade (Tabela 21), o maior valor médio foi obtido pelo cV. IRAT-112, embora nao se diferencia-se estatisticamente do cv. CNA-791041.

TABELA 19 - Valores de $F$ e coeficiente de variação para peso hectolitrico.

\begin{tabular}{lcc}
\hline Tratamentos / Locais & 01 & 02 \\
\hline Cultivares (C) & $19,68 \% *$ & $10,56 * \%$ \\
Adubações (A) & 2,66 & $6,68 *$ \\
Int. (CXA) & 1,85 & 1,72 \\
Blocos & 0,92 & 0,25 \\
\hline CV(\%) & 3,47 & 3,13 \\
\hline
\end{tabular}

TABELA 20 - Peso hectolítrico. Mëdias obtidas para os tratamentos no Local 01 .

\begin{tabular}{lrrrr}
\hline Cultivares & CNA-791041 & IRAT-112 & IAC-165 & Médias \\
Adubações & & & & \\
\hline Correção + Manutenção & 46,12 & 42,72 & 43,72 & 44,19 \\
Manutenção & 48,85 & 43,20 & 43,62 & 45,22 \\
\hline Médias & 47,48 & 42,96 & 43,67 & \\
\hline
\end{tabular}

d.m.s. (Tukey) $5 \%$ para cultivares $=2,01$ 
.60 .

A Tabela 21 revela também, pela comparação dos tratamentos aciubações, que a adubação de manutenção produziu sementes mais pesadas do que a adubação de correção + manuten ça.

TABELA 21 - Peso hectolitrico. Mëdias obtidas para os tratamentos no Local 02 .

\begin{tabular}{lcccc}
\hline Cultivares & CNA-791041 & IRAT-112 & IAC-165 & Médias \\
\hline Codubaçães & & & \\
\hline Manuteção + Manutenção & 55,02 & 57,70 & 52,32 & 55,01 \\
\hline Médias & 57,77 & 57,67 & 55,15 & 56,86 \\
\hline
\end{tabular}

d.m.s. (Tukey) $5 \%$ para cultivares $=2,27$

\section{2,3, PODER GERMINATIVO DAS SEMENTES}

Na Tabela 22 sao apresentados os valores de F para os tratamentos nos diferentes locais.

Verifica-se que houve nos locais 01 e 02 , dife rencas significativas para cultivares; no local 02 , de maior fertilidade, significāncia para adubações e para a inte ração cultivares $x$ adubações.

As médias dos tratamentos e as diferenças mini 
mas significativas para comparacao dessas médias, em ambos os locais, são apresentados nas Tabelas 23 e 24 .

TABELA 22 - Valores de F e coeficiente de variação para poder germinati do das sementes.

\begin{tabular}{lcc}
\hline Tratamentos / Locais & 01 & 02 \\
\hline Cultivares (C) & $7,39 * *$ & $8,12 * \%$ \\
Adubação (A) & 1,22 & $5,93 \%$ : \\
Int. (CXA) & 0,14 & $13,83 * \%$ \\
Blocos & 0,35 & 0,63 \\
\hline CV $(\%)$ & 8,48 & 1,58 \\
\hline
\end{tabular}

TABELA 23 - Poder germinativo das sementes (\%). Médias obtidas para os tratamentos no Local 01.

\begin{tabular}{lccccc}
\hline Cultivares & CNA-791041 & IRAT-112 & IAC-165 & Médias \\
Adubação & & & \\
\hline Correção + Manutenção & 82,25 & 73,50 & 87,50 & 81,08 \\
Manutenção & 87,25 & 75,75 & 88,75 & 84,25 \\
\hline Médias & 87,75 & 75,12 & 88,12 & \\
\hline
\end{tabular}

d.m.s. (Tukey) 5\% para cultivares $=9,11$ 
.62

TAEELF. 24 - Poder germinativo das sementes (\%). Mëdias obtidas para os tratamentos no Local 02.

\begin{tabular}{lrrrr}
\hline $\begin{array}{c}\text { Cultivares } \\
\text { Adubações }\end{array}$ & CNA-791041 & IRAT-112 & IAC-165 & Médias \\
\hline Correção + Manutenção & 95,25 & 97,25 & 91,75 & 94,75 \\
Manutenção & 93,75 & 97,25 & 97,75 & 96,25 \\
\hline Mëdias & 94,50 & 97,25 & 94,75 & \\
\hline
\end{tabular}

d.m.s. (Tukey) 5\% para cultivares $=1,96$

d.m.s. (Tukey) $5 \%$ para cultivares dentro de adubação $=2,77$

d.m.s. (Tukey) $5 \%$ para adubações dentro de cultivar $=2,27$

No Tocal 01, ce menor fertilidade (Tabela 23), foi menor o poder germinativo do cV. IRAT-112, significativamente diferente dos outros dois cultivares; enquanto que, no local 02, de maior fertilidade (Tabela 24), ao contrārio do sucedido no solo de menor fertilidade, O CV. IRÁT-112 se destacou pelo maior poder germinativo, apresentando média estatisticamente diferente dos demais cultivares.

A Tabela 24 revela também que, no local de maior fertilidade, maior poder germinativo das sementes foi obtido quando se empregou apenas a adubação de manutenção da cultura do arroz, sendo este resultado devido a significativa diferença apresentada pelo CV. IAC-165 entre os tratamentos a dubações. 


\section{$4,2,4$, VIGOR DAS SERENTES}

Na Tabela 25 são apresentados os valores de $F$ para os tratamentos nos dois locais.

De acordo com a Tabela 25 verifica-se que apenas no local 01 , de menor fertilidade, houve diferenca significativa para cultivares; e no $10 c a l$ 02, de maior fertilidade, somente diferença significativa para a interacão cultivares $x$ adubaçoes.

TABELA 25 - Valores de $F$ e coeficiente de variação para vigor das sementes.

\begin{tabular}{lcl}
\hline Tratamentos / Locais & 01 & 02 \\
Cultivares (C) & $21,13 * *$ & 1,55 \\
Adubaçōes (A) & 0,21 & 0,83 \\
Int. (CXA) & 1,32 & $7,04 \% *$ \\
Blocos & 2,57 & 2,44 \\
\hline CV $(\%)$ & 9,78 & 2,16 \\
\hline
\end{tabular}

As médias dos tratamentos e as diferencas min mas significativas pelo teste de Tukey, para ambos os locais, são apresentados nas Tabelas 26 e 27. 
TABELA 26 - Vigor das sementes (\%). Médias obtidas para os tratamentos no Local 01.

\begin{tabular}{lrrrr}
\hline Adubações & Cultivares & & & \\
\hline Correção + Manutenção & 72,00 & 61,25 & IAC-165 & Médias \\
\hline Manutenção & 80,00 & 58,75 & 83,25 & 72,16 \\
\hline Médias & 76,00 & 60,00 & 81,75 & 73,50 \\
\hline
\end{tabular}

d.m.s. (Tukey) $5 \%$ para cultivares $=9,25$

TABELA 27 - Vigor das sementes $(\%)$. Médias obtidas para os tratamentos no Local 02.

\begin{tabular}{lcccc}
\hline Cultivares & CNA-791041 & IRAT-112 & IAC-165 & Médias \\
\hline Adubações & 95,00 & 95,25 & 90,50 & 93,58 \\
Correção + Manutenção & 93,00 & 91,50 & 94,00 & 92,83 \\
\hline Manutenção & 94,00 & 93,75 & 92,25 & \\
\hline Médias & & \\
\hline
\end{tabular}

d.m.s. (Tukey) $5 \%$ para cultivares $=2,61$

d.m.s. (Tukey) $5 \%$ para cultivares dentro de adubação $=2,70$

d.m.s. (Tukey) $5 \%$ para adubações dentro de cultivar $=3,03$ 
A Tabela 26 mostra atravēs da anárise comparativa das médias dos cultivares, que no local 01 , de menor fer tilidade, o vigor das sementes do cv. IRAT-112 foi percentual mente menor do que o dos outros dois cultivares.

Na anālise da interação significativa cultivares x adubações no l.ocal 02 , de maior fertilidade (Tabela 27), observa-se dentro dos tratamentos adubacões, que o cr. IAC- 165 apresentou sementes mais vigorosas quando se fez apenas a adubação de manutenção da cultura; o inverso aconteceu com o cv. IRAT-112, ou seja, maior vigor das sementes foi obtido para este cultivar quando se fez, além da adubação de manuten cao, tambēm a correção do solo.

Anal isando-se os cultivares dentro das adubacoes, constata-se que quando se fez a adubação de correção + manu tenção, o cv. IAC-165 apresentou menor média de vigor das sementes e que quando se fez apenas a adubação de manutenção, esse mesmo cultivar obteve maior média para vigor.

\subsection{ANÁLISES DO SOLO}

Na Tabela 28 são apresentadas as médias dos resultados das análises quimicas do solo nos dois locais do experimento, realizadas antes da adubação corretiva e após a colheita das parcelas. 
.66 .

De acorcio com a referida tabela verifica-se que a adubação corretiva + manutenção proporcionou, em ambos os 10 cais, aumento dos teores de fósforo, cālcio + magnésio, cobre e zinco; e no local 01 , de menor fertilidade, aumento do teor de potāssio e diminuição do teor de aluminio.

Nos dois locais a adubação de manutenção foi responsāvel pela conservação dos teores de cālcio + magnésio, e pelo aumento do teor de fósforo; e conservaça do teor de potássio no local 01 , de menor fertilidade.

Através desta tabela confere-se tambēm, nos dois locais, o melhor nivel de fertilidade do solo na camada de $0-20 \mathrm{~cm}$ em relação a camada de $20-40 \mathrm{~cm}$ da superficie. 
.67.

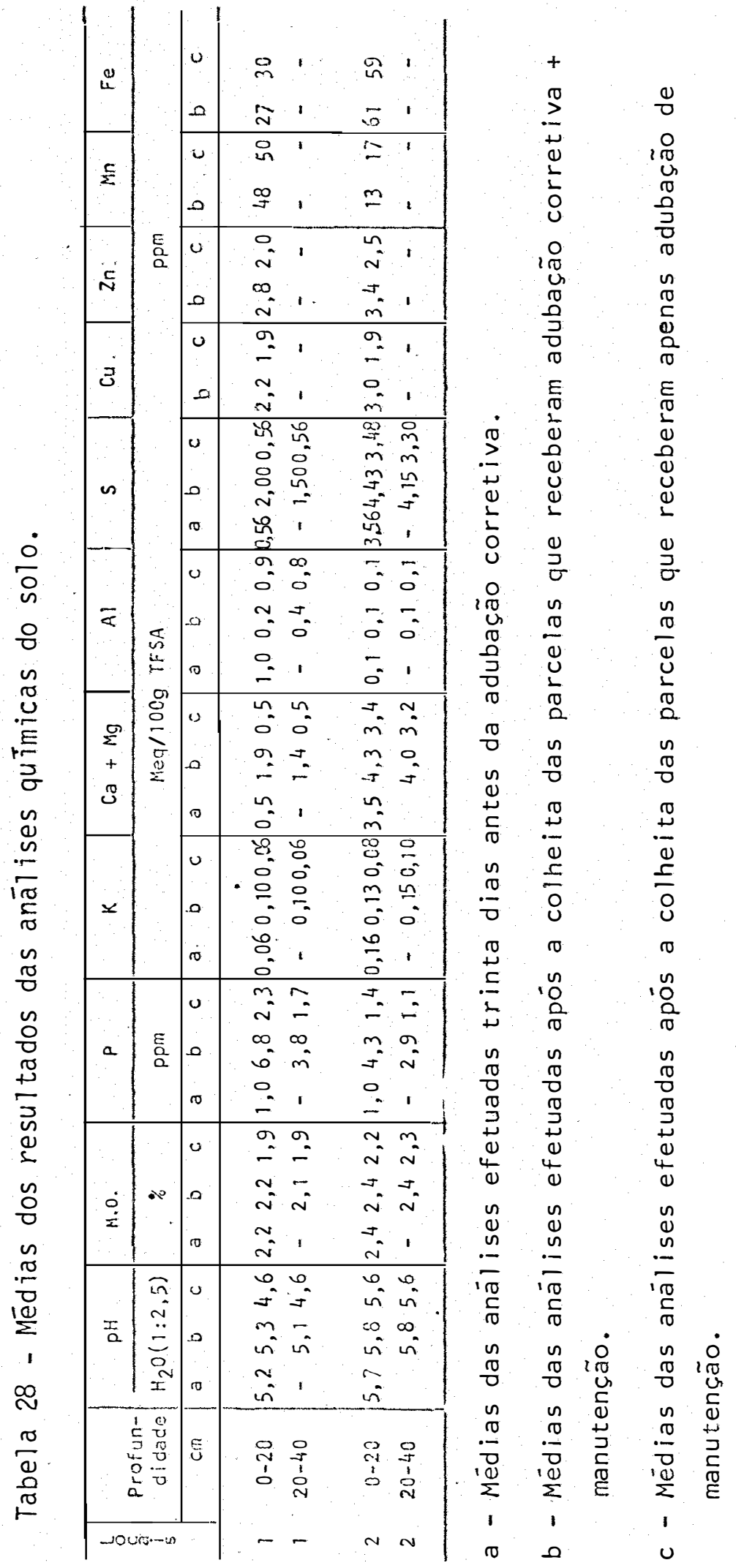


.68 .

\section{DISCUSSAO}

\subsection{DESENYOLVIMENTO E PRODUÇ̃̃O}

os resultados para nūmero de plantas por metro revelaram melhor comportamento do cV. CNA 791041 em relação aos outros dois cultivares em ambos os locais. No local 02, de maior fertilidade do solo (Tabela 03), o comportamento do 'CNA 791041' foi melhor no tratamento que se fez a adubação corretiva + manutenção. Considerando-se portanto, que as anālises foram realizadas aos 25 dias apōs a semeadura, quándo as reservas das sementes jā haviam se esgotadas, constatou-se que o cv. CNA 791041 foi o que mais aproveitou as condicões de disponibilidade de nutrientes. Observou-se nessa ocasião que este cultivar apresentou no local de maior fertilidade, maior altura e desenvolvimento que os demais. Por outro lado, em local de menor fertilidade, observou-se também que o 'IAC-165' era o cultivar que apresentava maior desenvol vimento.

A anāilise da altura das plantas mostrou que o

'IRAT-112' nos do is locais do experimento apresentou menor a? tura (Tabelas 05 e 06), o que era esperado, por se tratar de cultivar de pouco crescimento em ärea de cerrado. Quanto a 
fertilidade do solo ficou demonstrado, em local de maior fertilidade, a influência significativa da adubação corretiva no aumento da altura das plantas; tal fato não aconteceu no $10-$ cal de menor fertilidade, pois as plantas foram afetadas por periodos de deficiências hîdricas.

As anālises dos resultados obtidos para número de panīculas por metro mostraram que o tratamento adubação corretiva + manutenção levou a obtenção de maior nūmero de paniculas do que o tratamento adubação de manutenção (Tabelas 08 e 09). Este resultado vem ressaltar que a melhoria da fertilidade do solo, através da aplicação da matéria orgànica, da calagem, de fosfatagem e da aplicação de micronutrientes, é importante nas āreas de cerrado, mesmo em solos de boa fertilidade. No local de menor fertilidade (Tabela 08) a anālise de interação cultivares $x$ agiubacões mostrou que nem todos os cultivares apresentam resposta positiva à adubação corretiva: o cv. CNA 791041 não apresentou diferenças significativas entre os tratamentos adubações.

As anālises dos resultados de produção de grãos por parcela, evidenciaram diferenças significativas para tratamentos apenas no local de menor fertilidade. Nesse local (Tabela 11) ficou ressaltada a importância da adubação corretiva para a maior produção de grãos. Porém a interação cultivares $x$ adubacões mostrou que nem todos cultivares tiveram o mesmo comportamento quanto ao tratamento adubacões, pois - 'CNA 791041' não apresentou aumento de produção com a a duba 
cão corretiva. Este resultado inesperado talvez possa ser explicado pelo fato deste cultivar apresentar maior exigência quanto a fertilidade. Observou-se aos 65 dias do ciclo da cul tura, no emborrachamento das plantas, um período sêco (verāni co) de aproximadamente dez dias, que prejudicou mais as parce las com a adubação corretiva, de maior desenvolvimento vegeta tivo.

o fato do cv. IAC-165 ter se destacado dos outros dois cultivares quanto a produção de grãos, mostra sua a daptabilidade às condições do cerrado, justificando sua grande ārea de cultivo. Inúmeros trabalhos, como os conciuídos por KERRIDGE et alii (1971), HOWELER e CADAVID (1976), FAGERIA e ZIMMERMANN (1979) e FAGERIA e BARBCSA FILHC (1982), indicam diferenças entre cultivares na utilização de nutrientes e comportamento ao aluminio, e portanto adaptabilidade diferenciais.

CARMONA (19ju) enfatizou a importāncia da uti1 ização de um cultivar adaptado a região de cultivo, e o emprego de boas práticas culturais para aumentar o rendimento da lavoura. SANTIAGO (1981) em experimento com cultivares, ve rificou que o 'IAC-165' foi um dos que apresentou caracteristicas mais promissoras para o cerrado.

$$
\text { Comparando-se as produçóes obtidas ros dois }
$$

Tocais do experimento (Tabelas 11 e 12), observou-se que ocor reu uma grande diferença entre esses locais. No local de menor fertilidade a produção foi abaixo da média para a região. 
Considerando que o arroz é uma cultura rústica, pouco exigente em fertilidade, geralmente cultivado em ärea de cerrado apenas com adubação de manutenção, esperava-se que a produção fosse maior ao menos no tratamen to adubacão corretiva + manutenção. Porém através do acompanhamento do desenvolvimento da cultura nesse local, verificou-se que a precipitacão e a irri gacão suplementar não foram suficientes para atender a necessidade de āgua da cultura. Assim, houve periodos secos que prejudicaram o desenvolvimento das plantas e favoreceram o ataque de pragas e doenças. Aos 25 dias do ciclo das plantas houve ataque da cigarrinha das pastagens (Deois flavopicta), e no emborrachamento das plantas incidência da brusone (Pyricularia oryzae). Estas ocorrēncias explicam a baixa produção do local.

No local de maior fertilidade obteve-se uma produção acima da média normal para a região, não se registrando problemas fitossanitāios, sendo atendidas as necessidades hîjricas das plantas através da precipitação e da irrigação suplementar. Conforme jā descrito, as producões obtidas pelos cultivares no tratamento adubação corretiva + manutencão, em solo de maior fertilidade, não foram significantemente diferentes das producões obtidas no tratamento adubação de manutenção. Estes resultados conduzem a consideração de que, neste solo não houve necessidade da adubação corretiva para o aumento da produção; pode-se mesmo considerar que ela foi prejudicial, pois as observacões de campo mostraram para 
.72 .

este tratamento, um maior desenvolvimento vegetativo das plan tas, levando os cultivares 'CNA 79-1041' e 'IAC-165', de maior porte, ao acamamento na fase de frutificação. Segundo COSTA e OKUYAMA (1980), em solos de elevada fertilidade, a adubacão, principalmente a nitrogenada, deve ser feita com cautela, pois em doses elevadas predispõe a planta a acamamento.

0 rendimento em grãos inteiros no beneficiamen to do arroz é importante fator a ser considerado pelo produtor para a sua comercialização; quanto maior o rendimento maior serā o preço obtido no mercado. Comparando-se os rendimen tos em grãos inteiros nos dois locais (Tabelas 14 e 15), cons tatou-se que os rendimentos no local de menor fertilidade foram muito inferiores aos rendimentos normalmente obtidos nas mäquinas de beneficio, em torno de $55 \%$. A semelhança do que foi verificado para produção de grãos, pode-se justificar este resultado pelas condicões de desenvolvimento áa cultura, prejudicada por perīodos secos e pela alta incidência da brusone, principalmente na fase de frutificação. No local de maior fertilidade os rendimentos em grãos inteiros foram supe riores a média dos rendimentos, justificados pelas excelentes condições de desenvolvimento das plantas.

Analisando-se os cultivares, verificou-se que - 'IRAT 112' apresentou menor rendimento em grãos inteiros em ambos os locais. Porém deve ser considerado que, a grande quebra de grãos desse cultivar no local de menor fertilidade, foi devido ao maior ataque da brusone na fase de emissão das 
.73.

paniculas. O 'IAC-165', que se destacou peia sua producão de grãos, foi juntamente com o 'CNA 79-1041' o cultivar de ma is alto rendimento em grãos inteiros no beneficiamento. No local de maior fertilidade, os rendimentos em grãos inteiros do CV. CNA 79-1041 foram maiores no tratamento adubação de manutenção, isto porque os rendimentos do tratamento adubação corretiva + manutenção foram prejudicados devido ao acamamento das plantas na fase de frutificacão.

\subsection{QUALIDADE DAS SEMENTES}

E comum o produtor de arroz reservar parte da sua produção para ser utilizada como semente na instalação de nova cultura. Para tanto é importanie que essa semente seja de boa qualidade; assim sendo foram feitas as anālises de peso de 1000 sementes, peso hectolitrico, poder germinativo e vigor, com a finalidade de avaliar a possibilidade do aprove $\underline{i}$ tamento de parte da produç̃a como semente.

Pela interpretação dos resultados obtidos para os parāmetros analisados, pode-se inferir que a qualidade das sementes, conforme era de se esperar, foi melhor no local de maior fertilidade, pelas mesmas razões que justificaram a maior produção de grãos e maior renáimento em grãos inteiros no beneficiamento. Desse modo parte da producão de grãos provenientes desse locai poderia ser utilizada como semente. uma vez que apresentou padrão acima do exigido pela legislação. 
Interpretando-se tambëm os resultados encontra dos para esses mesmos parāmetros, constata-se que o cV. IRAT 112 foi o de melhor qualidade de sementes, devido ao maior pe so de 1000 sementes, peso hectolitrico, poder germinativo e vigor, no local de maior fertilidade. Os resultados obtidos no local de menor fertiliciace não devem ser considerados por terem sido prejudicados, principalmente pela incidéncia da brusone.

\subsection{ANÁL.ISES DO SOLO}

No presente experimento foram realizadas aduba coes corretiva e de manutencão. Na adubacão corretiva foram u tilizados matéria orgânica, aplicações de cālcio + magnésio e de fósforo, atravēs da calagem e da fosfatagem, e a aplicacão de micronutrientes.

Como matéria orgânica foi aplicado palha de arroz, em quantidade superior a normalmente deixada pela coTheita, com finalidade de favorecer as propriedacies fisicas do solo. A importância da utilização da matēria orgānica no solo foi enfatizada por PRIMAVESI (1978) e KIEHL (1981, 1985); na cultura do arroz MACHADO et alii (1985) demonstraram sua importância no aumento da produção de grãos; PONTE et alii (1971) obtiveram resultados positivos na cultura do arroz com aplicacões de esterco de curral associado ou não à adubação 
quîmica.

A aplicação de cālcio + magnésio através da calagem, é prática realizada com relativa frequēncia em areas de cerrado, porem, FAGERIA (1983) relatou que a recomendação da calagem para o arroz tem sido muito discutida, talvez devido ao pequeno número de trabalhos de pesquisa conduzi dos; VIEIRA et alii (1975) após vārias pesquisas em solos de cerrado, concluiram que a aplicacão de calcārio não propor cionou aumento da produção de arroz; jā GUAZZELLI et alị (1973) verificaram efeito significativo da aplicacão de calcá rio em arroz de sequeiro, em solo de textura arenosa.

A aplicação de fósforo em doses elevadas, atravēs da fosfatagem, vem sendo utilizada tambëm com relativa frequēncia em āreas de cerrado; VAN RAIJ et alii (1982), ao analisarem grande número de ensaios realizados nas diferentes regiōes do Brasil, relataram a importāncia dessa fosfatagem $\underline{\text { a }}$ lēm da adubação fosfatada de manutenção, no aumento da producão da maioria das culturas.

o emprego de micronutrientes é pouco utilizada em āreas de cerrado à excessão do zinco, porēm PANDE et al i $i$ (1976) concluiram pela importāncia da aplicação de micronutrientes em combinação com NPK, no aumento da produtividade do arroz. Quando ao zinco, jā estā mais do que comprovada a necessidade da sua utilização na cultura do arroz de sequeiro; trabalhos de CARVALHO et alii (1975), GALRÃO et alii (1978), BUZETTI et alii (1981) e VIEIRA et alii (1987) constataram os 
efeitos desse micronutriente.

$$
\text { A adubação de manutenção NPK }+Z n \text {, empregada }
$$

nas mesmas doses, nos dois locais do experimento, foi uma adu bação de restituicão, utilizada com finalidade de suprir as necessidades das plantas de arroz, nas quantidades recomendadas por EMBRATER/ENBRAPA (1979), MALAVOLTA (1979) e FAGERIA $(1983)$.

os resultados cias anālises do solo em ambos os locais, com niveis de fertilidade distintos, mostraram a importância da adubacão corretiva na melhoria de suas qualidades quimicas, devido ao aumento dos teores de fósforo, cāicio + magnēsio, zinco, cobre e soma de bases, e redução do teor de aluminio.

Portanto a adubação corretiva contribuiu para uma melhoria do solo e consequentemente um maior aproveitamen to de nutrientes das futuras culturas, porēm, foi verificado que para o local de maior fertilidade, onde as condicões para a cultura do arroz foram as mais adequadas, essa adubação aca bou determinando problemas aos cultivares de maior porte, que pelo excessivo desenvolvimento vieram a acamar; já no local de menor fertilidade, a adubação corretiva foi um fator de imporiància, contribuindo para uma maior produção em relação a simples adubação de manutenção.

Quanto a adubação de manutenção, pela comparação dos resultados das anālises efetuadas antes e apōs a cul tura do arroz, verifica-se que os teores de nutrientes no so- 
10, praticamente nao se alteraram; mas foi observado que, no local de maior fertilidade, a simples adubação de manutenção permitiu uma excelente produção de grãos, enquanto que no 10cal de menor fertilidade, a producão foi menor, devido a diversos fatores jā discutidos.

Estes resultados assemelham-se aos obtidos por MACHADO et alii (1979), que em experimento realizado no cerra do por dois anos consecutivos, utilizando calagem, fosfatagem e diferentes doses de fertilizantes, verificaram que as maiores produções foram btidas com adubação somente no sulco de semeadura, pois as plantas nos niveis mais altos de adubacão apresentaram maior altura e alta porcentagem de acamamento. 
.78 .

\section{CORCLUSÕES}

os resultacios obtidos permitiram as seguintes conclusões:

1) Dentre os très cultivares utilizados,

cV. IAC-165 è o que melhor se adapta as diferentes condições de solos de cerrado, devido a sua maior produtividace e rendi mento no beneficiamento. O CV. CNA-791041 e o CV. IRAT-112, são indicados apenas para solos de boa fertilidade.

2) Os grãos de arroz quando produzidos em condicões favorāveis de cultivo,e armazenados adequadamente, po derão ser utilizados como sementes.

3) A adubação corretiva, como a utilizada no experimento, melhora as propriedades quimicas do solo. Em so10 de baixa fertilidade e em condições adversas de cultivo, essa adubação é importante no aumento da produção do arroz. Em solo de alta fertilidade e em condicões favorāveis de curtivo, a adubação corretiva prejudica a produção do arroz devido ao acamamento das plantas. 


\section{REFERENCIAS BIBLIOGRÁFICAS}

ABRAHÃO, J.T.M. \& TOLEDO, F.F. Resultados preliminares de testes de vigor em sementes de feijoeiro. Revista de Agri-. cultura, Piracicaba, 11(1): 132-63, 1969.

ANDRADE, S. \& LIBONATI, V.F. Primeiros resultados experimentais sobre variedades de arroz, obtidos na Estação Experimental de Pedreiras. Belém, Instituto Agronōnico do Norte, 1962. p. 35-46 (Circular IAN, 6).

BANZATTO, N.V.; SANTOS, G.; AZZINI L.E. Inventärio tecnotógico. do arroz. Goiānia, EMBRAPA/CNPAF, 1975. p. 18-21.

BARBOSA FILHO, M.P. \& FAGERIA N.K. A ocorrēncia, diagnose e correçao da deficiēncia de zinco de arroz de sequeiro. Goiània, EMBRAPA/CNPAF, 1980. 18 p. (Circular Técnica, 4).

BLAIR, G.L.; MAMARIL C.P.; MAMUAT E. Sulfur nutrition of lowland rice. Los Baños, International Rice Researh Institute, 1978. 29 p. (IRRI Research Paper Series, 2). 
BUZETTI, S.; NASCIMENTO, V.M.; FERNANDES, F.M. Efeito de trés fontes e quatro niveis de zinco sobre a cultura de arroz de sequeiro em um Latossolo Vermeino cscuro. Il ha Solteira, UNESP, 1981. (Relatörio Técnico Cientîfico, 1).

CAMARGO, C.E.0.; CAMARGO, O.B. de A; SOUZA D.M. Tolerāncia de cultivares de arroz a diferentes niveis de aluminio em solução nutritiva. Bragantiä, Campinas, 42: 191-201, 1983 .

CARMONA, P.S. Fatores que influem na produção de arroz. Lavoura Arrozeira, Porto Alegre, 256: 33-4. 1970.

CARVALHO, Y. de; ALMEIDA NETO, J.X. de; VALLADARES, L.C.; BARBOSA, R.A.; RIBEIRO C.A.; NEIVA S, da L.C. Efeitos de niveis de zinco sobre a cultura do arroz em solo de cerrado. Anais da Escola de Agronomia e Veterināria, Goiānia, 5(1): $34-40,1975$.

CAVAlCANTE, J.I.V.; Silveira, J.F.; Vieira, M.G.F.C. Influência do nitrogênio, fósforo, potássio e zinco na germinação de sementes de arroz. Revista Brasileira de Sementes, Brasilia, $4(3): 27-33,1982$. 
CHHILLAR, R.K. \& SWARUP, A. Effect of continuous cropping and fertilizer use on soil properties and yields of rice and wheat in sodic soil. Indian Journal of Agricultural Sciences, New Delhi, 54(6): 461-6, 1984.

COQUEIRO, E.P.; FREIRE, B. de A.; PEREIRA, J. Efeito da aplicacão do calcário e enxofre em cultura de arroz de sequeiro. In: REUNIAO BRASILEIRA DE CERRADO, 2, Sete Lagoas, 1967. Sete Lagoas, IPEACO, 1972. p. 71-7.

COSTA A. Uso de fertilizantes na cultura do arroz. Uso de. fertilizantes na agricultura Paranaense. Londriria, IAPtR, 1980. p. 61-7. (Circular, 16).

COSTA A. \& OKUYAMA, L.A. Adubação da cuitura do arroz. Cuttura do Arroz no Estado do Paranā. Loncirina, IAPAR, (19): $39-47,1980$.

COUTO, W.S.; CORDEIRO A.C.C.; ALVES A.A.C. Dosagens de fósforo para cultivares de arroz em Latossolo de campo cerrado de Roraima. Belém, EMBRAPA-CPATU, 1982. 3 p. 
CRUZ, E. de S.; SOUZA, G.F., de; MAGALHAES, J.C.A.J.; BASTOS, J.B. Estudo de adubação em arroz, diferentes modalidades de adubar e corrigir os solos. In: PONTE, N.T. da. TrabaIhos Experimentais com fertilizantes. Belém, Secretaria de Agricultura, 1973. p. 125-32.

CRUZ, E. de S.; COUTO, W.S.; FIGUEIREDO, F.J.C.; KASS, D.L.; BASTOS, J.B. Adubação mineral NPK de arroz em Terra Roxa Estruturada, In: PONTE, N.T. da. Trabalhos experimentais. com fertilizantes: Belém, Secretaria da Agricultura, $1973 ;$ p. $133-7$.

EMBRAPA. Serviço Nacionai de Levantamento e Conservação de Solos. Manual de métodos de anālises de solos. Rio de Janeiro, 1979 .

EMBRATER/EMBRAPA - Empresa Brasileira de Assistēncia Técnica e Extensão Rural/Empresa Brasileira de Pesquisa Agropecuária. Sistemas de produção para arroz de sequeiro. Goiānia, 1979. 20 p. (Boletim, 171).

FAGERIA, N.K. Adubação e nutrição mineral da cultura do arroz. Rio de Janeiro, Editora Campus, EMBRAPA/CNPAF, 1984. 341 p. 
FAGERIA, N.K. Calagem para cultura do arroz. In: REUNIÃo BRASILEIRA DE FERTILIDADE DO SOLO, 15., Campinas, 1982. Acidez e Calagem no Brasif: Campinas, Sociedade Brasileira de Ciência do Solo, 1983.p. 227-44.

FAGERIA, N.K. Deficiēncia hídrica em arroz de cerrado e resposta ao fósforo. Pesquisa Agropecuāria Brasileira, Brasí$1 \mathrm{ia}, \underline{15}(3): 259-65,1980$.

FAGERIA, N.K. Deficiēncias nutricionais do arroz na identificação e correção. Dinâmica dos nutrientes no solo e na absorção pela cultura do arroz. In: CURSO DE PRODUç̃o DE ARROZ, 1., Goiānia, EMBRAPA/CNPAF, 1984. 95 p.

FAGERIA, N.K. Influência da aplicação de fósforo no crescimento, producão e absorcão de nutrientes no arroz irrigado. Revista Brasileira de Ciência do Solo, Campinas, 4(1): 26-3, 1975 .

FAGERIA, N.K. Resposta de cultivares de arroz à aplicação de calcārio em solos de cerrado. Pesquisa Agropecuāria Brasileira, Brasilia, 19(7): 883-8, 1984 . 
FAGERIA, N.K. Tolerāncia diferencial em cultivares de arroz ao a luminio em solução nutritiva. Pesquisa Agropecuāria. Brasileira, Brasilia, 17(1): 1-9, 1982.

FAGERIA, N.K. \& BARBOSA FILHO,M.P. Avaliação de cultivares de arroz para maior eficiência na absorção de fósforo. Pesquisa Agropecuäria Brasileira, Brasīlia, 16(6): 777-82, 1981 .

FAGERIA, N.K. \& BARBOSA FILHO,M.P. Avaliação preliminar de cultivares de arroz irrigado para maior eficiencia de utilização de nitrogénio. Pesquisa Agropecuäria Brasileira, Brasilia, 17(2): 1709-12, 1982 .

FAGERIA, N.K. \& ZIMMERMANN, F.J.P. Interação entre fósforo, zinco e calcário em arroz de sequeiro. Revista Brasileira. de Ciência do Solo, Campinas, 3(2): 88-92, 1979.

FAGERIA, N.K. \& ZIMMERMANN, F.J.P. Seleção de cultivares de arroz para toleráncia a toxidez de aluminio em solução nutritiva. Pesquisa Agropecuāria Brasileira, Brasīlia, 14: $141-7,1979$. 
FAHL, J.I.; CARELLI, M.L.C.; DEUBER, R.; NOGUEIRA S.S.S. Respostas de cultivares de arroz (oryza sativa L.) ao aluminio em solução nutritiva. Revista de Agricultura, Piracicaba, 57(4): 257-66, 1982 .

FREITAS, F.G. de; MOTHCI, E.P.; SANTOS, H.G. do; POTTER, R.0. Levantamento de Solos do Posto Agropecuārio e da Fazenda Capivara - Goiās. Goiãnia, EMBRAPA/CNPAF, 1975.

GALRAO, E.Z.; SUCHET, A.R.; SOUZA, D.M.G. de. Efeitos de micronutrientes no rendimento e composicão química do arroz (Oryza sativa L.) em solo de cerrado. Revista Brasileira de Ciência do Solo, Campinas, 2: 129- 32, 1978.

GIUDICI, R.M. de L.; FREIRE, F.M.; TANAKA, R.T. Nutrição mineral e adubação do arroz. Informe Agropecuärio, Belo Horizonte, 5(55): 40-50, 1979 .

GUAZZELLI, R.J.; MENDES, J.F.; BAUWIN, R.G.; MILLER, S.F. Efeitos agronómicos e econōmicos do calcário, nitrogênio, fósforo, potássio, enxōfre e micronutrientes nos rendimentos de soja, feijão e arroz em Uberaba, Minas Gerais. Pesquisa Agropecuāria Brasileira, Brasilia, 8: 29-37, 1973. 
.86.

HOWELER, R.H. \& CADAVID, L.F. Screening of rice cultivars for tolerance to Al toxicity in nutrient solutions as compared with a field screening method. Agronomy Journal, Madison, 68: $551-5,1976$.

KARIM, A.Q.M.B. \& VLAMIS, J. Micronutrient deficiency symptoms of rice grown in nutrient culture solutions. Plant and soil, The Hague, 16(3): 347-60, 1962.

KERRIDGE, P.C.; DWASON, M.D.; MOORE, D.P. Separation of degrees of aluminum tolerance in wheat. Agronomy Journal, Madison, 63: $586-91,1971$.

KIEHL, E.J. Fertilizantes orgänicos. Piracicaba, Editora Agronômica Ceres, 1985. $492 \mathrm{p}$.

KIEHL, E.J. Matēria orgānica. In: SEMANA DA MATERIA ORGĀNICA, Piracicaba, CALQ-ESALQ/USP, 1981. $12 \mathrm{p}$.

LEITE, M.0. \& BIRBAUMER, G. Adubação económica de arroz na região fisiogräfica dos cocais. São Luis, ACAR, Serviço de Extensão Rural, 1977. $14 \mathrm{p}$. 
LEITE, N.; GARGANTINI, H.; HUNGRIA, L.S.; IGUE, T. Efeitos do nitrogēnio, fósforo, câlcārio e micronutrientes em cultura de arroz irrigado no vale do Paraiba: Bragantia, Campinas, 29: 273-85, 1970 .

LINDSAY, W.L. \& NORVEWLL, W.A. Development at a DTPA test for zinc, iron, manganese and copper. Soil science Society of America journal, Madison, 42: 421-8, 1978.

MACHADO, M.O.; GOMES, A. da S.; DIAS, A.D.; ZONTA, E.P. Adubação orgânica e mineral na cultura do arroz irrigado no solo de Pelotas. In: REUNIF́o DA CULtURA do ARROZ IRRigado, 14 , Pelotas, 1985. Anais, Pelotas, CPATB/EMBRAPA/UFPEL, 1985. p. 187-95.

MACHADO, S.C.; MENDCNÇA, A.T.C.; FARIAS, J.C. Adubação fosfatada em arroz de sequeiro. In: EMGOPA. Relatório Técnico 1978. Goiānia, 1979. p.196-8.

MACLEOD, L.B. \& SUZUKI, M. Effects of $N, P$ and $K$ on chemica 1 composition of barley grown on a low-fertility podzol soil in the greenhouse. Canadian Journal of Soil Science, Ottawa, 52(2): 169-77, 1972 . 
MALAVOLTA, E. Nutrição mineral e a dubação do arroz de sequeiro. Piracicaba, Ultrafértil, 1979. 40 p. (Boletim Técnico).

MALAVOLTA, E.; HAAG, P.H.; MELLO,F.A.F.; BRASIL SOBRINHO, M.O.C. Nutrição mineral e adubação de plantas. São Paulo, Pioneira, 1974. p. $325-70$.

MALAVOLTA, E. \& ROCHA, M. Adubos minerais e orgānicos. In: SEMANA DA MATERIA ORGÂNICA, Piracicaba, CALQ-ESALQ/USP, $1981.25 \mathrm{p}$.

MISRA, A.K.; HAYAR, P.K.; PATNAIK, S. Uptake of Zn and Cu in relation to growth and yield of rice varieties of different durations. Indian Journal of Agricultura Sciences, New Delhi, 54(5): 395-403, 1984 .

MORAIS, O.P. \& GONTIJO, V. de P.M. Respostas da cultura de arroz (oryza sativa $L_{\text {.) }}$ de sequeiro à fertilização NPK e à calagem. In: EPAMIG. Projeto arroz-relatōrio anual 1975-76. Beto Horizonte, 1978. p, 93-138.

OLIVEIRA, D.A.; MONTOJOS, J.C.; IGUE, T. Adubação de arroz de sequeiro. II. Avaliacão de influência do nitrogênio, fósforo e potássio sobre as caracteristicas das variedades precoces de arroz de sequeiro. Bragantia, Campinas, $23(8): 73-81,1964$. 
OLIVEIRA, D.A.; MONTOJOS, J.C.; IGUE, T.; MIRANDA, H.S.;

FREITAS JUNIOR, M.L. Ensaios preliminares de adubação do arroz de sequeiro. III.Cultivar Dourado Precoce. Bragantia, Campinas, 25(1): 1-8, 1968.

PANDE, H.K.; SINGH, V.P.; MANNA, G.B. Effect of copper, zinc, boron, calcium, molybdenum application on yield and nutrient content of rice. Riso, Rome, 25(4): 325-32, 1976.

PONNAMPERUMA, F.N. The chemistry of submerged soils. Advances. in Agronomy, New York, 24: 29-96, 1972.

PONTE, A.M. da; TANAKA, R.T.; MORAIS, U.P. de; CASTILHO, J.A.B.; GUIMARAES, P.T.G.; FREIRE, F.M. Interação entre calcārio, fósforo e zinco na cultura do arroz em um solo sob vegetação de cerrado. Beto Horizonte, EPAMIG, 1979.. 9 p.

PONTE, N.T. da; THOMAS, M.C.; LIBONATI, V.F. Experimento de adubação em arroz de sequeiro. Boletim da Escola de Omia do Amazonas, Belém, (4): 5-13, 1971.

PRIMAVESI, A. Organic matter and soil productivity in the tropics and subtropics. In: cirganic matter and soil fertility. Amsterdam, North Holland Publishers, 1969. p. 553-96. 
RAIJ, B. van.; ROSAND, P.C.; LOBATTO, E. Adubação fosfatada no Brasil apreciação geral, conclusões e recomendações. In: 01 iveira, A.J. de; Lourenço, S.; Goedert, W.J. Adubação fosfatada no Brasil. Brasilia-EMBRAPA, p. 9-28, 1982.

SANTIAGO, G. Introdução de cultivares de arroz de sequeiro, ano agrícola 1979/80, em solo sob vegetacão de cerrado. Il ra Solteira, UNESP, 1981. p. 9-10. (Relatōrio Técnico Científico, 1).

SECRETARIA DE AGRICULTURA E ABASTECIMENTO DO ESTADO DE SÃO PAULO. Caracteristicas das cultivares de arroz recomendadas para

o Estado de São Paulo. Campinas, 1982. p. 11. (Bol. Informativo).

SMYTH, T.J. \& SANCHEZ, P.A. Nïveis criticos de fösforo para arroz de sequeiro em um Latossolo dos cerrados. Revista Brasileira de Ciēncia do Solo, Campinas, $4(1): 88-92,1980$.

SOUZA, D.M. de \& HIRCCE, R. Diagnose e tratamento preventivo no solo de deficiência de zinco em cultura de arroz de sequeiro em solos com pH abaixo de 7. Bragantia, Campinas, 29(9): $91-103,19 \%$. 
STONE, L.F.; OLIVEIRA, A.B., de; STEIMMETZ, S. Deficiēncia hîdrica e resposta de cultivares de arroz de sequeiro ao nitrogénio. Pesquisa Agropecuäria Brasileira, Brasilia, 14(3): $295-301,1979$.

TAVARES, F.C.A. Componentes de producão relacionados a heterose em hibridos intervarietais de mitho. Piracicaba, 1972. 106 p. Doutoramento - ESALQ/USP

VIEIRA, I.F.; PEREIRA, J.; REGO, A.S.; MORAES, E.A. Efeito de calagem e micronutrientes em arroz de sequeiro. In: CNPAF/ /EMBRAPA, Goiānia, Inventārio Tecnolōgico do arroz 1975. Goiānia, 1975. p.182-3.

VIEIRA, N.F. de; KLUTHCOUSKI, J.; OLIVEIRA, de I.P. Tratamento de sementes com micronutrientes. In: REUNIATO NACIONAL DE PESQUISA DO ARROZ, 3., Goiānia, 1987. Anais. Goiânia, CNPAF/EMBRAPA, 1987. p. 107. 